\title{
6458 SAYILI KANUN UYARINCA YAPILAN ULUSLARARASI KORUMA BAŞVURULARININ TÜRK IDARI YARGISINDA ELE ALINMASI
}

\author{
Kasım OCAK*
}

\section{$\ddot{O} Z$}

6458 sayll Yabanclar ve Uluslararast Koruma Kanunu ile birlikte daha önce dă̆ınık halde olan iltica/sı̆̆ınma mevzuatı bir bütün haline gelmiş ve kanuni dayanak kazanmıştır. Söz konusu kanun kullanılan terimler açısından da yenilikler getirmiştir. 6458 sayılı Kanun öncesinde kullanılan sı̆̆ınmacı kavramı yerine şartlı mülteci kavramı tercih edilmiş, bu kavram mülteci ve ikincil koruma statüsü ile birlikte uluslararası koruma türlerini oluşturmuştur. 6458 sayılı Kanun kapsamında yapılan işlemlerin yargısal denetiminde istisnası olmakla birlikte idari yargı görevli kılınmıştır. Uluslararası koruma başvurularının yapılma ve değerlendirilme usulüne dair ayrıntılı düzenlemeler içeren 6458 sayılı Kanun sonrasında oluşan uyuşmazlıklar idari yargının bu konudaki içtihatlarının zengin ve belirli olmasına neden olmuştur. 6458 sayıl Kanun kapsamında yapllan işlemlerde genel görevli mahkeme idare mahkemeleri olduğu için idari yargının bu alandaki içtihatlarının ele alınması gerek yabancılar hukukunun gelişimi gerek bu kanundan yararlanmak isteyen yabanciların hak kaybına uğramaması için önem arz etmektedir.

Anahtar Kelimeler: uluslararası koruma, mülteci, şartlı mülteci, idari başvuru, idari yargl

\section{DEALING WITH INTERNATIONAL PROTECTION APPLICATIONS MADE IN ACCORDANCE WITH THE LAW NO. 6458 IN THE TURKISH ADMINISTRATIVE JURISDICTION}

\section{ABSTRACT}

With the Law No. 6458 on Foreigners and International Protection, the refugeel asylum legislation, which was previously dispersed, has become a whole and has gained a legal basis. The law in question also introduced innovations in the sense of terms. The concept of conditional refugee was chosen instead of the concept of asylumseekers used before the Law No. 6458, which together with the refugee and secondary protection status established international protection types. The administrative jurisdiction is mandated, although there is an exception under the judicial review of the transactions carried out under Law No. 6458. The disputes that occurred after the

\footnotetext{
Arş. Gör., Galatasaray Üniversitesi Hukuk Fakültesi. e-posta: kasimocak@gmail.com.

ORCID: 0000-0001-9826-8336

DOI: $10.34246 /$ ahbvuhfd.637681

Yayın Kuruluna Ulaştığı Tarih

: 02/02/2019

Yayınlanmasının Uygun Görüldüğü Tarih: 18/09/2019
} 
Law No. 6458, which contained detailed regulations on the procedure for making and evaluating international protection applications, led to the fact that the case law of the administrative judiciary was rich and specific. Since the general competent court is the administrative courts in the proceedings under Law No. 6458, it is important to consider the case law of the administrative jurisdiction in this field both for the development of foreigners' law and for the foreigners who want to benefit from this law not to lose their rights.

Key Words: international protection, refugee, conditional refugee, administrative application, administrative jurisdiction.

\section{GÍRIŞ}

Türkiye'nin coğrafi konumu; Orta Asya, Kafkaslar, Ortadoğu ve Balkanlar gibi uluslaşma süreçleri, askeri müdahaleler, rejim değişiklikleri ile silahlı çatışmalar yaşanan ve bu sebeplerin toplu göçe ${ }^{1}$ yol açtığ bölgeleri birleştirmektedir. Türkiye bu bölgelerden yaşanan göçlerde son durak olabildiği gibi başka ülkelerin hedeflendiği göçlerde geçiş ülkesi de olabilmektedir. ${ }^{2}$ Söz konusu bölgeler arasındaki konumu nedeniyle Türkiye bu bölgeler arasında yaşanan göç hareketlerinde ana güzergahlardan biri haline gelmektedir. ${ }^{3}$ Gerçekten de Türkiye göç ve sığınma hareketlerine ilişkin Osmanlı Devleti dönemine dayanan bir tecrübeye sahiptir. Genellikle Osmanlı'ya sığınan insanların oluşturduğu bu tecrübelerin İspanya'dan gelen Yahudilerle başladığ 1 ifade edilmektedir. ${ }^{4}$

Son yıllarda dünya çapında meydana gelen silahlı çatışma, şiddet ve insan hakları ihlalleri sebebiyle göç eden insan sayısında büyük bir artış yaşanmıştır. ${ }^{5}$ Şüphesiz Suriye'de yaşanan ve yıllardır devam eden iç savaş

Uluslararası Göç Örgütü'ne göre göç; süresi, yapısı ve uzunluğu ne olursa olsun, devlet içinde ya da uluslararası sınırları geçerek bir kişinin ya da grubun yaptığı yer değiştirmedir. Bkz. http://www.iom.int/key-migration-terms, E.T. 25.12.2018.

2 Nurcan, ÖZGÜR/Yeşim, ÖZER. Türkiye'de Sığınma Sisteminin Avrupalılaştırılması, Derin Yayınları, İstanbul, 2010, s. 104.

3 Haydar, EFE. “Osmanlı İmparatorluğu ve Türkiye'de Yaşanan Göçler ve Etkileri”, Sosyal Bilimler Metinleri, Y. 2018, S. 1, s. 17.

4 ÖZGÜR/ÖZER, Ibid., s. 109.

5 Mülteci akımlarının sebepleri hakkında bkz. Oğuzhan, TÜRKOĞLU. "Mülteciler ve Ulusal/ Uluslararası Güvenlik”, Uludağ Üniversitesi İktisadi ve İdari Bilimler Dergisi, Y. 2011, C. XXX, S. 2, s. 105 vd. 
ve çatışmalar küresel düzeyde görülen göç hareketlerinin artışında dünyanın diğer yerlerinde meydana gelen çatışmalardan daha etkili olmuştur. ${ }^{6}$ Türkiye, Suriye'de devam eden iç savaşın da etkisiyle küresel düzeyde artan mültecilerden en çok etkilenen ülkelerden biri haline gelmiştir. Birleşmiş Milletler Mülteciler Yüksek Komiserliği’nin (BMMYK) istatistiklerine göre de Türkiye dünyada en çok mülteci ve sığınmacı barındıran ülkelerden biridir. ${ }^{7}$

Geçiş ülke konumunun yanı sıra Türkiye'nin mülteciler tarafından giderek hedef ülke olarak tercih edilmesi mülteci ve sığınmacılara ilişkin hukuki düzenlemeler ve uygulamaların önemini artırmaktadır. ${ }^{8}$ Türk hukukunda iltica ve sığınma konularını tüm yönleriyle düzenleyen bir kanun bulunmamaktaydı. Mevzuattaki bu dağınıklık kavram karmaşasına, belirli bir standart ve yeknesaklığın oluşmamasına neden olmuştur. Bu sebeple mülteci ve sığınmacılara ilişkin dağınık mevzuat eleştirilmiştir. ${ }^{9} 11.04 .2013$ tarih ve 28615 sayılı Resmi Gazete'de yayımlanarak yürürlüğe giren 6458 sayılı Yabanc1lar ve Uluslararası Koruma Kanunu'ndan (YUKK) önce Türkiye'ye yapılan iltica ve sığınma başvuruları “Türkiye'ye İltica Eden veya Başka Bir Ülkeye İltica Etmek Üzere Türkiye'den İkamet İzni Talep Eden Münferit Yabancılar ile Topluca Sığınma Amacıyla Sınırlarımıza Gelen Yabancılara ve Olabilecek Nüfus Hareketlerine Uygulanacak Usul ve Esaslar Hakkında Yönetmelik"10 (1994 Yönetmeliği) ve 1951 Tarihli Mültecilerin Hukuki Durumuna Dair Cenevre Sözleşmesi ${ }^{11}$ (Cenevre Sözleşmesi) ile 1967 tarihli

6 Şebnem, ÇAKRAN/Veysel, EREN. "Mülteci Politikası: Avrupa Birliği ve Türkiye Karşılaştırması”, Mustafa Kemal Üniversitesi Sosyal Bilimler Enstitüsü Dergisi, Y. 2017, C. 14, S. 39, s. 2.

7 United Nations High Commissioner for Refugee (UNHCR) Statistics, http://popstats.unhcr. org/en/overview, E.T. 25.12.2018.

8 Rona, AYBAY. Yabancılar Hukuku, İstanbul Bilgi Üniversitesi Yayınları, İstanbul, 2007, s. 109; Bülent, ÇİÇEKLİ. "Mülteci, Sığınmacı ve Göçmenler: Sınıflandırma ve Yasal Statünün Belirlenmesine İlişkin Sorunlar”, Vatandaşlık, Göç, Mülteci ve Yabancılar Hukukundaki Güncel Gelişmeler, TBB Yayınları, Ankara, 2010, s. 327; Sema, BUZ. "Türkiye Sı ğınma Sisteminin Sosyal Boyutu", TBB Dergisi, Y. 2008, S. 76, s. 129.

9 Rifat, ERTEN. "Yabanc1lar ve Uluslar aras1 Koruma Kanunu Hakkında Genel Bir Değerlendirme", Gazi Üniversitesi Hukuk Fakültesi Dergisi, C. XIX, Y. 2015, S.1, s. 43; Bülent, ÇİÇEKLİ. Yabancılar Hukuku, Seçkin Yayınları, Ankara, 2013, s. 242; Nuray, EKŞİ. Yabancılar Hukukuna İlişkin Temel Konular, Beta Yayınları, İstanbul, 2007, s. 57.

10 94/6169 say1lı Bakanlar Kurulu Kararıyla onaylanarak 30.11.1994 tarih ve 22127 say11 Resmi Gazete'de yayımlanarak yürürlüğe giren 1994 Yönetmeliği, 2014/6883 sayılı Bakanlar Kurulu Karariyla onaylanarak 22/10/2014 tarih ve 29153 say1lı Resmi Gazete'de yayımlanarak yürürlüğe giren Geçici Koruma Yönetmeliği ile yürürlükten kaldırılmıştır.

11 Cenevre Sözleşmesi'ne dair 359 Sayılı Onay Kanunu 05.09.1961 tarih ve 10898 sayılı 
ek protokole ${ }^{12}$ (1967 Protokolü) göre yapılmaktaydı.

6458 sayılı Yabancılar ve Uluslararası Koruma Kanunu'nun yürürlüğe girmesinden önce iltica ve sı̆̆ınma mevzuatının bazı terminolojik karışıklıklara sebep olduğu görülmektedir. ${ }^{13}$ Genel olarak " $ı r k l$, dini, vatandaşllğl, muayyen bir sosyal gruba mensubiyeti veya siyasi kanaatleri yüzünden zulme uğrayacă̆ından haklı olarak korktuğu için doğduğu, büyüdü̈̆ü, oturduğu ülkeyi terk eden kişi" olarak tanımlanabilecek ${ }^{14}$ mülteci kavramı hakkında Cenevre Sözleşmesi ve 1994 Yönetmeliği'nin getirdiği tanımlar farklılaşmaktadır. Cenevre Sözleşmesi'ne göre mülteci "ırkı, dini, tabiiyeti, belirli bir sosyal gruba mensubiyeti veya siyasi düşünceleri nedeniyle zulme uğrayacağından haklı sebeplerle korktuğu için vatandaşı olduğu ülkenin dişında bulunan ve bu ülkenin korumasindan yararlanamayan ya da söz konusu korku nedeniyle yararlanmak istemeyen; yahut tabiiyeti yoksa ve bu tür olaylar sonucu önceden mutaden ikamet ettiği ülke dlşında bulunan, oraya dönemeyen veya söz konusu korku nedeniyle dönmek istemeyen şahıs[tır]." ${ }^{15}$ Cenevre Sözleşmesi ile 1967 Protokolü esas alınarak hazırlanan 1994 yönetmeliği ise mülteciyi “Avrupa'da meydana gelen olaylar sebebiyle ırkl, dini, milliyeti, belirli bir toplumsal gruba üyeliği veya siyasi düşünceleri nedeniyle takibata uğrayacağından ${ }^{16}$ hakl olarak korktuğu için vatandaşı olduğu ülke dışında bulunan ve vatandaşı olduğu ülkenin himayesinden istifade edemeyen veya korkudan dolayı istifade etmek istemeyen ya da uyruğu

Resmi Gazete'de yayınlanmıştır.

121967 Protokolü’nü onaylayan 6/10266 sayılı Bakanlar Kurulu Kararı, 05.08.1968 tarih ve 12968 sayılı Resmi Gazete'de yayınlanmıştır.

13 Tevfik Odman, Türkiye'nin imzaladığı uluslararası belgelerin çevirilerinde ve Türk yabancılar hukuku doktrininde iltica ve sığınma kavramları açısından yaşanan karmaşaya dikkat çekmektedir. Bkz. Tevfik, ODMAN. Mülteci Hukuku, AÜSBF, Ankara, 1995, s. 188-191; AYBAY, Yabanc1lar Hukuku, s. 22. Özden Sav, sığınmac1 ve mülteci kavramları etrafında oluşan karışıklığa işaret etmiş ancak sığınmacı ve mülteci kelimelerinin köken itibariyle bir anlam farklılığı taşımadığından bahisle mülteci kelimesi yerine sığınmacı kelimesini kullanarak ayrı bir karışıklığa sebep olmuştur. Örneğin 1951 tarihli "Mültecilerin Hukuki Durumuna Dair Sözleșme" yerine "Sığınmacıların Hukuki Durumuna Dair Sözleşme" ifadesini kullanmıştır. Bkz. Özden, SAV. "Uluslararası Hukuk Açısından "Sığınma", "Göç", "Nüfus Mübadelesi”, "Vatansızlık" Gibi "Silahlı Çatışma” Bağlantılı Nüfus Sorunları”, TBB Dergisi, S. 2016 (124), s. 543 vd.

14 Çi̇ÇEKLİ, Yabancılar Hukuku, s. 237.

15 Mültecilerin Hukuki Durumuna Dair Cenevre Sözleşmesi, m. 1/A(2), R.G. T. 05.09.1961, S. 10898.

16 Cenevre Sözleşmesi metninde zulüm (persecution) kelimesi kullanılmışken, 1994 Yönetmeliği'nde yanlışlıkla takibat (prosecution) kelimesi kullanılmıştır. 
yoksa ve önceden ikamet ettiği ülke dışında bulunuyorsa oraya dönmeyen veya korkusundan dolayı dönmek istemeyen yabancı" olarak tanımlamıştır.

1994 Yönetmeliği, Türkiye'nin Cenevre Sözleşmesi’ne koymuş olduğu coğrafi sınırlamaya ${ }^{17}$ uygun olarak yalnızca Avrupa'da meydana gelen olaylar sebebiyle mülteci statüsü tanınmasına olanak vermektedir. 1994 Yönetmeliği, Cenevre Sözleşmesi'nde geçmemesine ${ }^{18}$ rağmen sığınmacı kavramına da yer vermiştir. Buna göre mülteci statüsü yalnızca Avrupa'da meydana olaylar nedeniyle verilebilirken sı̆̆ınmacı statüsü Avrupa dışından gelip mülteci kriterlerini taşıyan yabancılara verilecektir. Belirtilmelidir ki 1994 Yönetmeliği’nin getirmiş olduğu bu sığınmacı kavramı, uluslararası literatürde kullanıldığından farklıdır. Uluslararası literatürde mülteci (refugee), mültecilik statüsünün hukuken kazanılmasını ifade ederken, sığınmacı (asylum seekers) ise mültecilik statüsü incelenen ve bu nedenle kendisine geçici koruma sağlanan kişi anlamına gelmektedir. ${ }^{19}$ Bir başka deyişle, bir kişi mülteci olduğunu iddia ediyor ama iddiaları henüz kesinliğe kavuşmamış ise bu kişi sığınmacı olarak tanımlanır. ${ }^{20}$

Görüldüğü üzere Türkiye'nin Cenevre Sözleşmesi'ne koyduğu coğrafi sınırlandırma sebebiyle mülteci tanımı uluslararası literatürden uzaklaşmış, sığınmacı tanımı ise coğrafi sınırlamaların yarattığı sorunlar sebebiyle yine uluslararası hukuktan farklı, Türkiye'ye özgü bir hal almıştır. 6458 sayılı Yabanc1lar ve Uluslararası Koruma Kanunu ise mülteci ve sığınma statülerini uluslararası koruma üst başlığı altında toplamıştır. Ancak 6458 sayılı Kanun'da

17 AİHM, Türkiye'nin Cenevre Sözleşmesi'ne koymuş olduğu coğrafi sınırlandırmanın Avrupa İnsan Hakları Sözleşmesi'nin, sözleşmede düzenlenen hakların cinsiyet, ırk, renk, dil, din gibi unsurlara dayanarak ayrımcılık yapılmadan herkes için sağlanması gerektiğini düzenleyen 14. maddesine aykırı olmadığına karar vermiştir. Bkz. AİHM, A.G. ve Diğerleri, Başvuru No. 40229/98, 15.06.1999.

18 Sı̆̆ınma kavramı Cenevre Sözleşmesi’nde yer almazken İnsan Hakları Evrensel Beyannamesi'nin 14. maddesinde sı ğınma kavramına yer verilmiştir. Avrupa Birliği Temel Haklar Şartı'nın 18. maddesinde de yer verilen sığınma hakkının değerlendirilmesi için bkz. Neva Övünç, ÖZTÜRK. “Avrupa Birliği Temel Haklar Şartında Yer Alan Sığınma Hakkının Tahlili”, İnönü Üniversitesi Hukuk Fakültesi Dergisi, Y. 2012, C. 3, S. 2.

19 ÇIÇEKLİ, Yabancılar Hukuku, s. 238; ODMAN, Ibid., s. 189; Ender Canan, EROĞLU/ Ruken, TAŞKIRAN. "Sığınma Hakk1 ve Mültecilerin Durumu”, TBB Dergisi, S. 2002/1, s. 109; Nasih Sarp, ERGÜVEN/Beyza, ÖZTURANLI. "Uluslararası Mülteci Hukuku ve Türkiye”, AÜHFD, Y. 2013, S. 62 (4), s. 1020. Eda Bozbeyoğlu, mülteciliğin sebepleri ve saikleri açısından tekil bir insanlık durumu olduğunu ve mülteci ve sığınmacı gibi teknik ayrımların insan hakları kuramı bakımından kabul edilemeyeceğini belirtmiștir. Bkz. Eda, BOZBEYOĞLU. "Mülteciler ve İnsan Hakları”, Moment Dergi, Y. 2015, S. 2 (1), s. 63.

20 https://www.unhcr.org/tr/siginma-basvuru-sahipleri, E.T. 26.12.2018. 
sığınmacı kavramına yer verilmemiş, uluslararası koruma çeşitleri mülteci, şartlı mülteci ve ikincil koruma olarak belirlenmiştir. ${ }^{21}$ YUKK'nın tanımları incelendiğinde şartlı mülteci kavramının 1994 Yönetmeliği’ndeki sığınmac1 kavramına karşılık gelecek şekilde kullanıldığ1 görülmektedir.22 Söz konusu kanuna göre mülteci veya şartlı mülteci olarak nitelemeyen ve kanunda yazılan diğer şartları taşıyanlar ikincil koruma statüsü alabilecektir. ${ }^{23}$ YUKK'nın 92. maddesinde uluslararası koruma süreçlerinde BMMYK ile ișbirliği de düzenlenmiştir. Buna göre "Sözleşme ${ }^{24}$ hükümlerinin uygulanmasina nezaret etme görevini yerine getirmesinde, BMMYK ile gerekli iş birliği să̆lanır."

${ }^{21} 6458$ sayılı Kanun'un 3/r. maddesi uluslararası korumayı "Mülteci, şartlı mülteci veya ikincil koruma statüsü” olarak tanımlamıştır. Zaman zaman 6458 sayılı Kanun'un 91. maddesinde düzenlenen geçici koruma, uluslararası koruma statülerinden biri sanılmaktadır. Ancak YUKK uyarınca bir yabancının uluslararası korumadan faydalanabilmesi için mülteci, şartlı mülteci ya da ikincil koruma statülerinden birine sahip olması gerekmektedir. Bkz. Neşe Baran, ÇELIKK. "Türk Hukukunda Uluslararası Koruma Başvurusunda Bulunan veya Uluslararası Korumadan Yararlanan Yabancıların Hak ve Yükümlülükleri”, İnönü Üniversitesi Hukuk Fakültesi Dergisi, Özel Say1, Y. 2015, C. 1, s. 73. Geçici Koruma Yönetmeliği'nin 16. maddesinde geçici koruma süresince uluslararası koruma başvurularının işleme alınmayacağı hüküm altına alınmıştır. Bu durumun uluslararası korumaya erişimi engellediği ve Cenevre Sözleşmesi'ne aykırılık taşıdığına ilişkin değerlendirme için bkz. Neva Övünç, ÖZTÜRK. "Geçici Korumanın Uluslararası Koruma Rejimine Uyumu Üzerine Bir İnceleme", Ankara Üniversitesi Hukuk Fakültesi Dergisi, Y. 2017, S. 66 (1), s. 249. 6458 sayılı Kanun'un uluslararası koruma statüleri olan mülteci, şartlı mülteci ve ikincil korumanın tanımları ile geçici korumaya ilişkin hükümlerinin ve Geçici Koruma Yönetmeliği'nin toplumsal cinsiyet konusunda duyarsız kaldığı̆, cinsel yönelimleri sebebiyle zulüm gören LGBTİ bireylerini yok saydığına yönelik eleştiri için bkz. Zeynep, KIVILCIM. "Yabancılar ve Uluslararası Koruma Kanunu ile Geçici Koruma Yönetmeliği: Toplumsal Cinsiyet Perspektifinde Bir Değerlendirme", Ankara Üniversitesi SBF Dergisi, Y. 2016, C. 71, S. 3, s. 939.

22 ERTEN, Ibid., s. 44. Şartlı mülteci statüsü Türkiye'nin Cenevre Sözleşmesi'ne koymuş olduğu sinırlamadan kaynaklanan Türk hukukuna özgü bir statüdür. Bkz. ÇELIKK, “Türk Hukukunda ...", s. 72.

${ }^{23} 6458$ sayılı Kanun'un 'İkincil Koruma' başlıklı 63. maddesi şöyledir: (1) Mülteci veya şartlı mülteci olarak nitelendirilemeyen, ancak menşe ülkesine veya ikamet ülkesine geri gönderildiği takdirde;

a) Ölüm cezasına mahkûm olacak veya ölüm cezası infaz edilecek,

b) İşkenceye, insanlık dışı ya da onur kırıcı ceza veya muameleye maruz kalacak,

c) Uluslararası veya ülke genelindeki silahlı çatışma durumlarında, ayrım gözetmeyen şiddet hareketleri nedeniyle şahsına yönelik ciddi tehditle karşılaşacak,

olması nedeniyle menşe ülkesinin veya ikamet ülkesinin korumasından yararlanamayan veya söz konusu tehdit nedeniyle yararlanmak istemeyen yabancı ya da vatansız kişiye, statü belirleme işlemleri sonrasında ikincil koruma statüsü verilir.

24 Sözleşme ile Mültecilerin Hukuki Durumuna Dair 1967 Protokolüyle değişik 28/7/1951 tarihli Mültecilerin Hukuki Durumuna Dair Sözleşme kastedilmektedir. Bkz. 6458 sayılı Kanun, m.3/p. 
Ayrıca “BMMYK'nın uluslararası koruma başvurusunda bulunmuş kişilere sinır kapıları da dâhil olmak üzere erişimi ve başvuru sahibinin de kabul etmesi şartıyla, başvurusuyla ilgili bilgilere erişimi sağlanır. BMMYK, başvurunun her aşamasında görüşlerini yetkililere iletebilir."

6458 sayılı Kanunda, uluslararası koruma statülerinin tanımları yanında, kimlerin uluslararası korumadan yararlanamayacağı, uluslararası koruma statüsü için başvuru, değerlendirme ve karar usulü, başvuru sahiplerinin ve statüsü kabul edilenlerin hakları ve yükümlülükleri, uluslararası koruma statüsünün sona ermesi, iptali, idari itiraz ve yarg1 yolu, idari gözetim gibi konular detaylı bir şekilde düzenlenmiştir. Böylelikle daha önce dağınık bir mevzuatta yer alan iltica ve sığınma başvuruları, uluslararası koruma kavramı altında toplanmış ve 6458 sayılı YUKK ile sistematik ve kanuni bir dayanağa kavuşmuştur. ${ }^{25}$

YUKK'nın 80. maddesinde uluslararası koruma başvurusu sonucu alınan kararlara karşı itiraz ve yargı yolu usulü belirlenmiştir. Söz konusu maddeye göre "ilgili kişi veya yasal temsilcisi ya da avukatı tarafindan kararın tebliğinden itibaren on gün içinde Uluslararası Koruma Değerlendirme Komisyonuna itiraz edilebilir." Ancak başvuru sahiplerinin idari gözetimi, yapılan başvurunun kabul edilemez bulunması ve hızlandırılmış değerlendirme sonucu alınan kararlara karşı yalnızca yargı yoluna başvurulabilecektir. Başvurucu tarafindan yapılan itirazın olumsuz sonuçlanması durumunda "ilgili kişi bir avukat tarafindan temsil edilmiyorsa kararın sonucu, itiraz usulleri ve süreleri hakkında kendisi veya yasal temsilcisi bilgilendirilir."

Başvurunun kabul edilemez bulunması kararı ve hızlandırılmış değerlendirme sonucu alınan kararlara karşı, kararın tebliğinden itibaren on beş gün, YUKK kapsamında alınan diğer idari işlemlere ${ }^{26}$ karş1 ise kararın tebliğinden itibaren otuz gün içinde yetkili idare mahkemesinde iptal davas1 açılabilecektir. Başvurunun kabul edilemez bulunması kararı ve hızlandırılmış değerlendirme sonucu alınan kararlara karşı idari yargıda açılan davaların on beş gün içinde sonuçlandırılacağı ve idari yargı yerlerince verilen bu kararların kesin olduğu yine aynı maddede hüküm altına alınmıştır. Uluslararası koruma başvurusunda bulunan kişi, itiraz ve yargılama süreci boyunca ülkede kalabilecektir.

25 ERTEN, Ibid., s. 45.

26 YUKK'nın 68/7. maddesi uyarınca başvurucular hakkında alınan idari gözetim kararına karşı sulh ceza hakimine başvurulabilmektedir. 
$\mathrm{Bu}$ makale kapsamında uluslararası koruma statülerinin şartları, uluslararası koruma başvurusunun yapılış ve değerlendiriliş usulü ayrıca ve detaylıca ele alınmayacak olup idari yarg1 yerlerinin uluslararası koruma başvurusunun yapılması (I) ve sonuçlandırılmasına (II) ilişkin içtihat ve değerlendirmelerine yer verilecektir. 6458 say1lı Kanun öncesindeki uyuşmazlıklar makalenin kapsamı dışında kalmakla birlikte konu bakımından ihtiyaç duyuldukça bu kararlara da değinilecektir.

\section{ULUSLARARASI KORUMA BAŞVURUSUNUN YAPILMASI}

6458 sayı11 YUKK'nın 65. maddesinde uluslararası korumaya başvuru usulü düzenlenmiştir. Buna göre uluslararası koruma başvuruları valiliklere bizzat yapılmalıdır. ${ }^{27}$ Esas olan başvurunun valiliklere yapılması olmakla birlikte başvurunun kolluk birimlerine yapılması durumunda başvuru valiliklere iletilir ve ilgili işlemler valilik tarafından yürütülür. ${ }^{28}$

Her yabancı veya vatansız kişi esas olarak kendi adına başvuru yapabilir. Ancak ergin olan aile üyelerinin muvafakat vermesi koşuluyla bir kişi, kendisiyle birlikte gelip aynı gerekçelere dayanan aile üyeleri adına da başvuru yapabilecektir.

Uluslararası koruma başvurusunun yapılması ve incelenme sürecine dair gerek başvurucunun (A) gerek idarenin (B) bazı yükümlülükleri bulunmaktadır.

\section{A. Başvurucunun Yükümlülükleri}

Başvurucunun başvuru yaptığı ülke mevzuatı tarafından birtakım yükümlülüklere tabi kılınması olağandır. Nitekim Cenevre Sözleşmesi'nin 2. maddesinde göre de "her mültecinin, bulunduğu ülkeye karşı, özellikle yasalara, yönetmeliklere ve kamu düzeni için alınan önlemlere uyma yükümlülükleri vardır." YUKK'nın da çeşitli maddelerinde başvuruculara bazı yükümlülükler getirilmiştir. Örneğin başvurucular, başvuru "esnasında

\footnotetext{
Mülga 1994 Yönetmeliği’nde de iltica ve sığınma başvurularının valiliklere yapılacağ düzenlenmişti. Türkiye'ye yasal yollardan gelenler bulundukları yer valiliklerine, yasal olmayan yollardan gelenler ise giriş yaptıkları yer valiliklerine gecikmeden müracaat etmekteydi.

286458 sayılı YUKK'nın 78. maddesine göre başvurular Göç İdaresi Genel Müdürlüğü tarafından sonuçlandırılacaktır. Göç İdaresi Genel Müdürlügü ve hukuki statüsü hakkında detaylı bilgi için bkz. Elif, ALTINOK ÇALIŞKAN. Mülteciler ve Sığınmacılar Hakkında İdarenin Görevleri-Yetkileri ve Yargısal Denetim, Yayımlanmamış Doktora Tezi, Dokuz Eylül Üniversitesi, İzmir, 2013, ss. 102-124.
} 
kimlik bilgilerini doğru olarak bildirmek ve varsa kimliğini ispatlayacak belge ve seyahat dokümanların yetkili makamlara teslim etmekle yükümlüdür."29 Başvurucunun kimliğine ilişkin bilgilerin elinde olmaması halinde "kimlik tespitinde kişisel verilerinin karşılaş̧tırılmasından ve yapılan araştırmalardan elde edilen bilgiler kullanılır. Kimlik tespit araştırmaları sonucunda da kimliğine dair bilgi elde edilememesi hâlinde, başvuranın beyanı esas alınır." ${ }^{30} \mathrm{Bu}$ gibi yükümlülüklerin yanı sıra söz konusu kanunun 90. maddesinde de başvuru sahibi ile uluslararası koruma statüsü sahiplerinin tabi olduğu ortak bazı yükümlülükler düzenlenmiştir. ${ }^{31}$ Kanunda düzenlenmiş olan yükümlülüklerden başvurunun yapıldığ 1 süre (1) ve başvurucunun bildirim yükümlülüğü (2) idari yargı kararlarında öne çıkan hususları oluşturmaktadır.

\section{Makul Sürede Başvuru Yapılması}

Başvurucunun başvurusunu yapması için tabi olduğu süre sınırlamasına ilişkin koşullar Türk hukukunda zaman içinde değişiklik göstermiştir. $\mathrm{Bu}$ bakımdan 6458 sayılı Kanun uyarınca yapılacak uluslararası koruma başvurusunun bir süre sınırlamasına tabi olup olmadığ 1 ve bu sürenin yapılan başvurunun sonucuna etkisi önem arz etmektedir.

1994 Yönetmeliği ilk yürürlüğe girdiği tarihte, yasal olmayan yollardan ülkeye giriş yapan yabancılara ülkeye giriş yaptıkları tarihten itibaren beş gün içinde yetkili makamlara başvuru yapmalarını zorunlu kılmaktaydı. $\mathrm{Bu}$ sürenin kısa olmasının yol açtığı sıkıntılar sebebiyle daha sonra bu süre on güne çıkarılmıştır. Ancak idari yargı yerleri, yalnızca bu süreye uyulmamasının sınır dış1 etme sebebi olamayacağına karar vermiştir. ${ }^{32}$

296458 say1l YUKK, m. 69/2.

${ }^{30} 6458$ say1lı YUKK, m. 69/3.

316459 sayılı YUKK'nın 90/1. maddesi şu şekildedir: (1) Başvuru sahibi veya uluslararası koruma statüsü sahibi kişi, bu Kısımda yazılı yükümlülüklerine ek olarak;

a) Çalışma durumuna ait güncel bilgileri otuz gün içinde bildirmekle,

b) Gelirlerini, taşınır ve taşınmazlarını otuz gün içinde bildirmekle,

c) Adres, kimlik ve medeni hâl değişikliklerini yirmi iş günü içinde bildirmekle,

ç) Kendisine sağlanan hizmet, yardım ve diğer imkânlardan haksız olarak yararlandığının tespit edilmesi hâlinde, bedellerini tamamen veya kısmen geri ödemekle,

d) Genel Müdürlükçe kendisinden bu Kısım çerçevesinde istenilenleri yerine getirmekle, yükümlüdür.

32 Ankara Bölge İdare Mahkemesi'nin 25.01.2000 tarihli kararı için bkz. EKŞİ, Yabancılar Hukukuna İlişkin..., s. 65; Rahatsızlığı sebebiyle süresi içinde idareye başvuramayan, dolayısıyla yasal ikamet izni alamayan kişi hakkında tesis edilen sınır dışı etme işleminin 
Uygulamada ortaya çıkan sorunlar sebebiyle 1994 Yönetmeliği'nde yapılan değişiklik ile on günlük süre kaldırılmış, başvuruların 'gecikmeden' yapılmas1 gerektiği düzenlenmiştir. ${ }^{33} \mathrm{Bu}$ değişikliğin, 1994 Yönetmeliği’ni Danıştay ve idari yargı yerlerinin süreye dair vermiş oldukları kararlar ile uyumlu hale getirdiği ve süresi içinde başvuru yapamayan yabancıların karşılaştıkları sorunlara ilişkin etkili bir çözüm olduğu ifade edilmiştir. ${ }^{34}$

Cenevre Sözleşmesi'nde iltica başvurularının yapılmasına dair bir süre sınırlaması bulunmamaktadır. ${ }^{35}$ Sözleşmenin 31 . maddesinde mültecilerin gecikmeden yetkili makamlara başvurmaları ve yasadışı giriş ve bulunuşlarının sebeplerini açıklamaları halinde ülkeye yasadışı girişleri sebebiyle kendilerine ceza verilemeyeceği belirlenmiştir. 6458 sayılı YUKK' da da başvuru süresine dair somut bir sınır bulunmamaktadır. Ancak Cenevre Sözleșmesi'nin 31. maddesine benzer şekilde kanunun 65/4. maddesinde "makul bir süre içinde valiliklere kendiliğinden uluslararası koruma başvurusunda bulunanlar hakkında; yasa dışı girişlerinin veya kalışlarının geçerli nedenlerini açılklamak kaydiyla, Türkiye'ye yasal giriş şartların ihlal etmek veya Türkiye'de yasal şekilde bulunmamaktan dolayı cezai işlem yapılma[yacağı]" düzenlemesine yer verilmiştir.

Her ne kadar kanunda somut bir süre sınırına yer verilmediyse de başvurucunun makul olmayan sürede uluslararası koruma başvurusunda bulunması, idari yargı yerleri tarafindan başvurunun reddine dair işlemi hukuka uygun kılan nedenlerden biri olarak tespit edilmektedir.

Örneğin, Mısır'da aldığı eğitim ve inancı nedeniyle Tacikistan'a döndüğünde kötü muameleye maruz kalma ve öldürülme endişesi yaşadığını iddia eden ve uluslararası koruma başvurusu idare tarafindan reddedilen bir

iptaline dair bkz. D. 10. D., E. 1999/154, K. 2000/2756, T. 25.05.2000. Bkz. Nuray, EKŞİ/ Bülent, Çi̧̇EKLİ. Yabancılar ve Mülteci Hukukuna İlişkin Danıştay 10. Daire Kararları, Beta Yayınevi, İstanbul, 2012, s. 132. Süresinde yapılmayan başvurunun sınır dış1 sebebi sayılmadığına ilişkin bkz. D. 10. D., E. 2004/8769, K. 2007/2735, T. 18.05.2007; D. 10. D., E. 1999/746, K. 2000/5403, T. 25.10.2000; D. 10. D., E. 1999/5050, K. 2001/823, T. 14.03.2001; D. 10. D., E. 1999/5194, K. 2001/821, T. 14.03.2001. bkz. EKŞİ/ÇİÇEKLİ, Ibid., s. 134 vd.

33 Türkiye'ye İltica Eden veya Başka Bir Ülkeye İltica Etmek Üzere Türkiye'den İkamet İzni Talep Eden Münferit Yabancılar ile Topluca Sığınma Amacıyla Sınırlarımıza Gelen Yabancılara ve Olabilecek Nüfus Hareketlerine Uygulanacak Usul ve Esaslar Hakkında Yönetmelikte Değişiklik Yapılmasına Dair Yönetmelik, m. 1, R.G. T. 27.01.2006, S. 26062.

34 EKŞİ, Yabancılar Hukukuna İlişkin..., s. 66.

35 Çi̇çEKLİ, Yabancılar Hukuku, s. 255. 
kişinin açtığı davada Danıştay, başvurucunun Türkiye'ye 11/11/2012 tarihinde giriş yapmasına rağmen "vize ihlali" suçundan hakkında işlem yapılmasının ardından Geri Gönderme Merkezine sevk edildiği 07/01/2015 tarihinde, makul olarak kabul edilemeyecek bir süre sonra uluslararası koruma talebinde bulunmasını idarenin işlemini hukuka uygun kılan sebeplerden biri olarak kabul etmiştir. ${ }^{36}$

Hristiyan olan ve bunun İran hükümeti tarafindan bilindiğini, ülkesine giderse kötü muameleye maruz kalacağını iddia eden bir kişinin uluslararası koruma başvurusunun reddedilmesi üzerine açtığı başka bir davada Danıştay, yine başvurucunun başvuru süresini karar verirken dikkate almıştır. Yüksek Mahkeme, idarenin başvurunun reddine dair işlemini hukuka uygun bulurken esas aldığ1 noktalardan biri de başvurucunun Türkiye'ye giriş tarihi olan 21/11/2013'den sonra makul olarak kabul edilemeyecek bir süre sonrasında 25/08/2014 tarihinde uluslararası koruma talebi başvurusunda bulunması olmuştur. ${ }^{37}$

Ancak belirtilmeli ki Danıştay'ın söz konusu kararlarında makul olmayan sürede yapılan başvurunun tek başına idarenin başvurunun reddine dair işlemini hukuka uygun kıldığına dair bir ibare bulunmamaktadır.

Uluslararası koruma başvurusunda bulunan kişilerin başvuru yaptıktan sonra da uymakla yükümlü olduğu bazı yükümlülükler bulunmaktadır.

\section{Bildirim Yükümlüllüğü}

6458 say1lı YUKK'nın 71. maddesine göre uluslararası koruma talep eden "başvuru sahibine, kendisine gösterilen kabul ve barınma merkezinde, belirli bir yerde veya ilde ikamet etme zorunluluğu ile istenilen şekil ve sürelerde bildirimde bulunma gibi idari yükümlülükler getirilebilir." Yine aynı kanunun 82. maddesinde ise "şartlı mülteci ve ikincil koruma statüsü sahibi kişiye, Genel Müdürlükçe, kamu düzeni veya kamu güvenliği nedeniyle belirli bir ilde ikamet etme, belirlenen süre ve usullerle bildirimde bulunma yükümlülüğü getirilebil[eceği]” düzenlenmiştir. 6458 sayılı Kanun, ikamete dair yükümlülüklerde Avrupa Birliği Konseyi Kabul Koşulları Yönergesi ile aynı esasları benimsemiştir. ${ }^{38}$

36 D. 10. D., E. 2016/2776, K. 2016/3849, T. 25.10.2016. Bkz. Lexpera İçtihat ve Bilgi Bankas1.

37 D. 10. D., E. 2016/2459, K. 2016/3908, T. 28.10.2016. Bkz. Lexpera İçtihat ve Bilgi Bankas1.

38 ÇELİK, "Türk Hukukunda...", s. 135. 
Başvurucunun mazeretsiz olarak, bildirim yükümlülüğünü üç defa üst üste yerine getirmemesi ve belirlenen ikamet yerini izinsiz terk etmesi ya da ikamet yerine gitmemesi, YUKK'nın 77/ç. maddesi uyarınca başvurunun geri çekilmiş kabul edilmesine neden olmaktadır. Bu durumda başvurunun değerlendirmesi durdurulmaktadır.

Devlet ile gerek vatandaşları gerek yabancı olup bazı haklardan faydalanan bireyler arasında karşılıklı bir yükümlülük ilişkisi bulunmaktadır. Buna göre bireylerin gerek ulusal, gerek uluslararası hukuktan kaynaklanan taleplerini devletin yetkili kurumlarına iletme ve bu kurumların da bireylerin taleplerini hukuk kuralları çerçevesinde karşılama yükümlülüğü bulunmakla birlikte; bireylerin de taleplerinin karşılanması noktasında devlet mekanizmasının harekete geçebilmesi için kendilerine yüklenen yükümlülüklere uygun davranması gerekmektedir. ${ }^{39}$

Buradan hareketle uluslararası koruma başvurusunda bulunan başvurucuların da bildirim yükümlülüğüne uymaları gerektiği ortadadır. Başvurucuların bu yükümlülüklerin yerine getirilmesine engel olacak bir mazeretleri bulunduğunda bu mazeretlerini ispatlayacak gerekli bilgi ve belgeleri idareye bildirme yükümlülüğ̈̈ de bulunmaktadır. ${ }^{40}$ Ayrıca söz konusu mazeretlerin bilgi ve belgeye dayalı olması yetmemekte, mazeretlerin geçerli ve kabul edilebilir olmaları da gerekmektedir.

Örneğin, Ankara Bölge İdare Mahkemesi, birkaç ay ruhsal olarak zor bir dönem geçirmesi, havaların çok soğuk olması ve yoğun kar yağış1 gibi nedenlerin imza yükümlülüğünü yerine getirmesine engel olduğunu iddia eden kişinin geçerli bir mazereti olmaksızın bildirim yükümlülüğünü yerine getirmediğine ve idarenin uluslararası koruma başvurusunun geri çekilmiş sayılması kararının hukuka uygun olduğuna karar vermiştir. ${ }^{41}$

Danıştay'ın da başvurucunun bildirim yükümlülügünü yerine getirmeme mazeretinin doğruluğunu ve kabul edilebilirliğini titiz bir şekilde incelediği görülmektedir. Örneğin, Elazı ̆̆ ilinde ikamete tabi tutulan ve bildirim yükümlülüğünü yerine getirmeyen bir kişi, maddi durumunun el vermemesi

Ankara BİM, 10. İDD., E. 2017/540, K. 2017/674, T. 13.9.2017. Bkz. Lexpera İçtihat ve Bilgi Bankası.

40 Ankara BİM, 10. İDD., E. 2017/540, K. 2017/674, T. 13.9.2017. Bkz. Lexpera İçtihat ve Bilgi Bankası.

${ }^{41}$ Ankara BİM, 10. İDD., E. 2017/540, K. 2017/674, T. 13.9.2017. Bkz. Lexpera İçtihat ve Bilgi Bankası. 
sebebiyle Ankara'da bağışçıların kendisi için kiraladığ 1 evde oturduğunu, ikamet ilinde ev kiralayacak maddi gücü olmadığ 1 için bildirim yükümlülüğünü yerine getiremediğini iddia etmiştir. Hakkında alınan başvurunun geri çekilmiş sayılması kararına karşı iptal davası açan davacının mazereti, ilk derece mahkemesince kabul edilerek başvurunun geri çekilmiş sayılması kararı iptal edilmiştir. ${ }^{42}$ Ancak Danıştay, başvurucun idareye yapmış olduğu itiraz dilekçesinde "ellerindeki tüm parayı Ankara'da kiraladıkları evin bir ylllı peşin kirasına verdikleri" yönündeki beyanının başvurucunun diğer iddialarıyla çeliştiğini ve idare tarafından Valilik Sosyal Yardımlaşma Vakfi, Kızılay ve diğer sosyal yardımlaşmaya ilişkin sivil toplum kuruluşlarından yardım alınabileceğinin belirtildiğini tespit ederek ekonomik sebeplerden dolayı Elazı ̆ iline gidilmemesinin mazeret olarak değerlendirilemeyeceğine karar vermiştir. ${ }^{43}$

Bildirim yükümlülügünün ihlal edilebileceği diğer ihtimal ise başvurucunun ikamet ilini izinsiz terk etmesidir. Danıştay bu durumda da başvurucunun ikamet ilini izinsiz terk etme gerekçelerini ayrıntılı şekilde incelemektedir. Örneğin, Çankırı ilinde ikamete uygun görülen ancak ikamet ilini izinsiz olarak terk eden başvurucunun, aslında izin alarak ikamet ilini terk ettiğine yönelik iddiası somut bir bilgi ve belgeye dayanmadığ için kabul edilmemiş ve idarenin vermiş olduğu uluslararası koruma başvurusunun geri çekilmiş sayılması kararı hukuka uygun bulunmuştur. ${ }^{44}$

Başvurunun geri çekilmiş sayılmasına dair kararlara süresi içinde itiraz edilmesi ve yargıya başvurulması başvurucunun daha sonra hak kaybı yaşamaması açısından önem taşımaktadır. Zira başvurusu geri çekilmiş sayılan kişiler hakkında 6458 sayılı YUKK'nın 54/i. maddesi uyarınca sınır dışı etme kararı alınabilecektir. Bu kararlara idari yargıda açılan dava sonucu idare mahkemelerinin vermiş olduğu kararlar kesin olup, bu kararlar aleyhine istinaf veya temyiz başvurusunda bulunulamamaktadır. Dolayısıyla kendisine gösterilen ikamet yerini izinsiz terk eden bir başvurucu, idarenin başvurunun geri çekilmiş sayılması işlemine karşı ilgili mercilere süresi içinde itiraz etmezse, başvurucu hakkında 6458 sayılı kanunun 54. maddesinin (i) bendi uyarınca sınır dışı edilme kararı alınabilecek ve bu işlemin iptali istemiyle

\footnotetext{
42 Ankara 1. İdare Mahkemesi, E. 2015/1738, K. 2015/2227, T. 12.11.2015. Bkz. Lexpera İçtihat ve Bilgi Bankası.

43 D. 10. D., E. 2016/1252, K. 2016/3847, T. 25.10.2016. Bkz. Lexpera İçtihat ve Bilgi Bankas1.

44 D. 10. D., E. 2016/3216, K. 2017/911, T. 21.2.2017. Bkz. Lexpera İçtihat ve Bilgi Bankas1.
} 
açılan dava sonucunda ilk derece mahkemesinin vereceği karar kesin olacaktır. $^{45}$

Başvurucuların başvuru ve değerlendirme süreçlerine ilişkin yükümlülükleri bulunduğu gibi idarelerin de başvurunun değerlendirilme sürecine ilişkin bazı yükümlülükleri bulunmaktadır.

\section{B. İdarenin Yükümlülükleri}

Uluslararası koruma başvurularının değerlendirilme aşamasında başvuruların adil bir şekilde sonuçlandırılması ve başvurucuların hak kaybına uğramaması için idarenin de üzerine düşen yükümlülükler vardır. YUKK'nın 70. maddesi bu yükümlülüklere örnek gösterilebilir. Buna göre "başvuru sahibi, başvurusuyla ilgili takip edilecek usuller, başvurusunun değerlendirilmesi sürecindeki hak ve yükümlülükleri, yükümlülüklerini nasıl yerine getireceği ve bu yükümlülüklere uymaması ya da yetkililerle iş birliğinde bulunmaması hâlinde ortaya çıkabilecek muhtemel sonuçlar, itiraz usulleri ve süreleri konusunda kaylt esnasında bilgilendirilir." Ayrıca başvuru yolunun etkin kullanılabilmesi için talep halinde, başvuru ve mülakat aşamalarında tercümanlık hizmetinin sağlanacağı aynı maddede hüküm altına alınmıştır. Avrupa İnsan Hakları Mahkemesi'ne (AİHM) göre de başvurucu takip edilecek prosedür hakkında bilgilendirilmeli ve idare ile başvuran arasında güvenilir bir sistem olmalıdır. ${ }^{46} \mathrm{AIIHM}$ 'in kabul ettiği bu gereklilikler de başvurucunun ihtiyaç duyduğunda tercüman hizmetinin sağlanmasını gerektirmektedir. Yine mülteci koruma sisteminin olmazsa olmazı olarak nitelenen 'erişilebilir bir uluslararası koruma başvuru prosedürü' oluşturmanın da idarenin görevlerinden olduğu söylenebilecektir. ${ }^{47}$

İdarenin yükümlülüklerinden başvurucu hakkında bilgi toplama (1) ve başvurucu ile mülakat yapma (2) görevleri idari yargı kararlarına konu olabilmektedir.

\section{Bilgi Toplama}

6458 sayılı YUKK'nın 93. maddesi idarenin bilgi toplama yükümlülüğünü düzenlemektedir. Buna göre "uluslararası koruma başvuruları incelenirken, etkin ve adil karar verebilmek, başvuran tarafindan iddia edilen hususların

45 D. 10. D., E. 2016/2507, K. 2016/3696,T. 11.10.2016. Bkz. Lexpera İçtihat ve Bilgi Bankas1.

46 AİHM, M.S.S./Belçika ve Yunanistan, Başvuru No. 30696/09, 21.01.2011, para. 301.

47 Bülent, Çi̧̇EKLİ. Yabancılar ve Mülteci Hukuku, Seçkin Yayınevi, Ankara, 2016, s. 319. 
doğruluğunu tespit edebilmek amactyla menşe, ikamet ve transit ülkelerle ilgili Birleşmiş Milletler Mülteciler Yüksek Komiserliği kaynaklarl ve diğer kaynaklardan güncel bilgi toplanır."

Görüldüğü üzere bilgi toplama görevi, kanun tarafından uluslararas1 koruma başvurularının etkin ve adil sonuçlanmasının araçlarından biri olarak nitelenmiştir. Menşe ülke bilgisi ve iltica bilgi sistemlerinin kurulması, uluslararası koruma statüleri açısından en çetrefilli konulardan birini oluşturmaktadır. Bu bilgi sistemlerinin iyi çalışması ve idarenin bilgi toplama yükümlülügünü yerine getirmesi, gerçekten uluslararası korumaya ihtiyacı olanlar ile başka amaçlar için uluslararası korumayı 'kılıf' olarak kullananların ayırt edilmesini sağlayacaktır. ${ }^{48}$ Anayasa Mahkemesi'ne göre de "sınır dışı etme işlemi sonucunda yabancının gönderileceği ülkede kötü muamele yasağının ihlal edileceğinin iddia edilmesi halinde idari ve yargisal makamlar tarafindan söz konusu ülkede gerçek bir ihlal riskinin bulunup bulunmadĭ̆ı ayrıntıl şsekilde araştırılmalıdır."

$\mathrm{Bu}$ önemle uyumlu olarak, idarenin başvurucuların iddiaları hakkında bilgi toplama görevini gereği gibi yerine getirmemesi uluslararası koruma başvurusunun reddi işlemini hukuka aykırı kılabilmektedir. Örneğin, ailesinin Hristiyan olduğunu ve bunun da İran Hükümeti tarafindan bilindiğini, bu nedenle İran'a geri gönderilmesi halinde kötü muameleye maruz kalacağını iddia eden kişinin uluslararası koruma başvurusu reddedilmekle birlikte Danıştay, 6458 sayılı kanunun 93. maddesindeki bilgi toplama görevinin yerine getirilmemesi nedeniyle başvurunun reddi işlemini hukuka aykırı bulmuştur. ${ }^{50}$

Ankara İdare Mahkemesi de Rusya'ya dönmesi halinde muhalif düşünceleri ve yaşadığı olaylar nedeniyle zulüm görme korkusu yaşadığını beyan eden başvurucunun iddialarının, Cenevre Sözleşmesi ve ulusal mevzuat uyarınca idare tarafından araştırılmadığını tespit etmiş ve bu nedenle eksik incelemeye dayalı olan uluslararası koruma başvurusunun reddi işlemini iptal etmiştir. ${ }^{51}$ İlk derece mahkemelerinin, istinaf ve temyiz merciine kıyasla bu

\footnotetext{
48 Nuray, EKŞİ. Yabancılar ve Uluslararası Koruma Hukuku, Beta Yayınevi, İstanbul, 2016, s. 200.

49 AYM, Azizjon Hikmatov Başvurusu, Başvuru No. 2015/15582, 10.05.2017, R.G. T. 07.06.2017, S. 30089, para. 56.

50 D. 10. D., E. 2016/1747 K. 2016/3913 T. 28.10.2016. Bkz. Lexpera İçtihat ve Bilgi Bankas1.

51 Ankara 1. İdare Mahkemesi, E. 2015/945, K. 2016/88, 20.01.2016. Bkz. http://
} 
gerekçeye dayanarak daha fazla karar verdikleri görülmüştür. ${ }^{52}$ Ancak verilen bu kararlar Bölge İdare Mahkemesi ve Danıştay tarafından ayrıntılı şekilde incelenip bozulabilmektedir.

İdarenin bilgi toplama yükümlülüğünün yanı sıra başvurular hakkında sahip olduğu bilgileri somut şekilde belgelemek ve aldığı kararları bu somut belgelere dayandırma yükümlülüğü de bulunmaktadır. Danıştay, bir başvurucu hakkında dayanağını ispatlamadan tahdit kodu koyan ve uluslararası koruma başvurusunu red gerekçesi hakkında hiçbir somut bilgi ve belge göstermeyen idarenin bu işlemini hukuka aykırı bularak iptal etmiştir. ${ }^{53}$ İdarenin başvuru hakkında adil bir karar verilmesi için üzerine düşen görevler, bilgi toplama yükümlülüğ̈̈ kadar başvurucu ile yapılan mülakatı da kapsamaktadır.

\section{Mülakat}

YUKK'nın 75. maddesinde başvurucunun uluslararası koruma başvuru kaydından itibaren otuz gün içinde bireysel mülakat yapılacağı öngörülmüş̧ür. Sözkonusu düzenlemede, mülakatın amacı idarenin bilgi toplama yükümlülüğü ile aynı olacak şekilde 'etkin ve adil karar verebilmek' olarak belirlenmiştir. Mülakatta başvurucunun başından geçenlerin zulüm ya da zulüm görme korkusu niteliğinde olup olmadığının tespiti hedeflenmektedir. ${ }^{54}$

Mülakatta başvurucunun kendisini en iyi şekilde ifade etmesine imkan tanımak idarenin görevidir. Mülakatın bireysel yapılması esas iken, aile üyelerinin de mülakatta bulunması gerekli görülürse, kişinin muvafakati alınmak kaydıyla mülakat aile üyeleriyle birlikte yapılabilir. Ayrıca başvurucunun talebi üzerine, avukatı mülakata gözlemci olarak katılabilir. Mülakatın özel ihtiyacı olan yabancılarla yapılması durumunda idare bu kişilerin özel durumlarını göz önüne almalıdır. Örneğin, çocuğun mülakatına psikolog, çocuk gelişimcisi, sosyal gelişimci, ebeveyni veya yasal temsilcisi durumun gereklerine göre katılabilirler.

Mülakat yapılmasına kadar geçen sürede yaşadıkları sebebiyle başvuru sahibi serbestçe konuşup kendisini ifade etmekte güçlük çekebilir. Bu nedenle

www.izmirbarosu.org.tr/Upload/files/haberler/ANKARA\%201_\%20İDARE\%20 MAHKEMESI\%20-2016-88.pdf, E.T. 26.12.2018.

52 Kayseri 1. İdare Mahkemesi, E. 2016/93, K. 2017/904, T. 18.05.2016; Ankara 1. İdare Mahkemesi, E. 2014/2267, K. 2016/451, 24.02.2016.

53 D. 10. D., E. 2016/2825, K. 2017/697, T. 13.2.2017. Bkz. Lexpera İçtihat ve Bilgi Bankas1.

54 ÇİÇEKLİ, Yabancılar ve Mülteci Hukuku, s. 338.

378 Ankara Hacı Bayram Veli Üniversitesi Hukuk Fakültesi Dergisi C. XXIII, Y. 2019, Sa. 4 
başvurucunun olguları doğru şekilde ortaya koyabilmesi için gerekli ortam sağlanmalı ve gerekirse bir mülakat daha yapılmalıdır. ${ }^{55}$

Mülakatların görüntülü ve sesli kayıt altına alınması zorunluluğu bulunmamakla birlikte bunun tercih edilmesi durumunda başvurucu bilgilendirilir. Ancak her mülakat sonunda tutanak düzenlenmesi ve bir örneğinin başvurucuya verilmesi zorunluluk arz etmektedir. Başvurunun reddedilmesi durumunda açılacak davalarda, idari yargı yerlerinin mülakat tutanağını da dikkate aldıkları görülmektedir.

Mülakat, başvurunun etkin ve adil sonuçlanmasında önemli bir araç olmakla birlikte kararda etkili olan tek araç değildir. Başvurunun sonuçlanmasına etki eden bir faktör olarak mülakatın yapılma zamanı ile başvurunun sonuçlanması arasında geçen zamanın uzunluğu yargılamaya etki eden bir unsur olabilmektedir.

Danıştay, bir kararında mülakat zamanı ile başvurunun sonuçlanması arasında uzun bir zaman bulunmasının başvurunun reddedilmesini hukuka aykırı kıldığı iddiasını incelemiş̧ir. Söz konusu davada, uluslararası koruma başvurularının başvurucunun sadece mülakatındaki beyanları esas alınarak değerlendirilmediği, uluslararası koruma statüsü için mevzuatta yer alan diğer unsurlarla birlikte değerlendirme yapıldığı dikkate alınarak, mülakatın üzerinden uzun bir zaman geçmesinin tek başına başvurunun reddi işlemini hukuka aykırı hale getirmeyeceği sonucuna varılmıştır. ${ }^{56}$

Ancak bu zaman diliminin uzunluğu bazı hallerde başvurunun reddedilmesi işlemini hukuka aykırı kılabilmektedir. Örneğin, başvurucunun başvurusunun değerlendirilmesine esas olan mülakat raporunun 16.06.2005 tarihli olduğu ve başvurunun reddi işleminin de 11.04.2013 tarihli olduğu bir uyuşmazlıkta, Ankara 1. İdare Mahkemesi, 6458 sayılı YUKK'nın 11.04.2013 tarihinde yürürlüğe girmesi nedeniyle kanun yürürlüğe girdikten sonra kanuna göre yapılmış bir mülakat ile başvurunun değerlendirilmesi gerektiğine, aksi takdirde hukuka aykırılık oluşacağına karar vermiştir. ${ }^{57}$

YUKK'nın 75. maddesinde başvuru kaydından itibaren otuz gün içinde

55 Ibid., s. 323.

56 D. 10. D., E. 2016/3517 K. 2016/3851 T. 25.10.2016. Bkz. Lexpera İçtihat ve Bilgi Bankas1.

57 Ankara 1. İdare Mahkemesi, E. 2015/945, K. 2016/88, 20.01.2016. Bkz. http:// www.izmirbarosu.org.tr/Upload/files/haberler/ANKARA\%201_\%20IDARE\%20 MAHKEMESI\%20-2016-88.pdf, 
mülakat yapılacağı ve aynı kanunun 78. maddesinde başvuru kaydından itibaren en geç altı ay içinde karar verileceği düzenlendiği için mülakat tarihi ile başvurunun karara bağlanması arasında uzun bir sürenin olmayacağ1 görülmektedir.

Başvurunun yapılması ve değerlendirme sürecine ilişkin bu yükümlülüklerin başvurucu ve idare tarafından gereği gibi yerine getirilmesi başvurunun adil şekilde sonuçlanmasını sağlayacaktır.

\section{ULUSLARARASI KORUMA BAŞVURUSUNUN SONUÇLANMASI}

Uluslararası koruma başvurusu, öncelikle başvuru sahibinin verdiği bilgiler 1şığında, idarenin başvurucunun verdiği bilgileri teyit ve araştırması sonucunda karara bağlanacaktır. ${ }^{58}$ YUKK'nın 78. maddesi 'karar' başlığını taşımaktadır. Bu maddeye göre kayıt tarihinden itibaren altı ay içinde karar verilir. Bu süre zarfında karar verilememesi halinde başvurucuya bildirilir.

Esas olan kararın bireysel verilmesi iken aile adına yapılan başvurular bütün olarak karara bağlanır ve verilen karar tüm aile üyelerini kapsar. Başvurucu hakkında karar verilirken, menşe veya önceki ikamet ülkesinin mevcut durumu ile başvurucunun kişisel durumu göz önünde bulundurulur. Başvurucunun zulüm veya ciddi zarar görme tehlikesiyle karşı karşıya olduğu menşe veya önceki ikamet ülkesinde güvenli bir bölge bulunması ve bu bölgeye güvenli bir şekilde seyahat imkanı olması durumunda uluslararası koruma başvurusu reddedilebilir.

Verilen karar, ilgili, yasal temsilcisi veya avukatına tebliğ edilir. Kararın olumsuz olması durumunda maddi gerekçeleri ve hukuki dayanakları da başvurucuya bildirilir. Avukat tarafindan temsil edilmeyen başvuruculara kararın sonucu, itiraz usulleri ve süreleri hakkında bilgilendirme yapılır.

Başvurunun sonuçlanması bağlamında, idari yarg1 kararlarında başvurunun reddi kararının denetlenmesinde bazı etkenler ön plana çıkmaktadır. Bu etkenler; başvurucunun 'gerçek bir risk' ile yüz yüze olması (A), BMMYK'nın başvurunun sonucuna olan etkisi (B) ve başvurucunun beyanları arasında çelişkiler bulunması (C) olarak belirlenmiştir.

58 ÇİÇEKLİ, Yabancılar ve Mülteci Hukuku, s. 323.

380 Ankara Hacı Bayram Veli Üniversitesi Hukuk Fakültesi Dergisi C. XXIII, Y. 2019, Sa. 4 


\section{A. Başvurucunun Gerçek Bir Risk ile Yüz Yüze Olması}

Uluslararası koruma başvurularının değerlendirilmesinde başvurucunun 'zulme uğramaktan haklı nedenlerle korku' ${ }^{59}$ yaşayıp yaşamadığı anahtar rol oynamaktadır. ${ }^{60}$ Korku ve bu korkunun haklı nedenlere dayalı olmas 1 gibi sübjektif ve nesnel iki unsurdan oluşan bu durumun başvurucu özelinde değerlendirilmesi kişisel ve nesnel durumların birlikte ele alınmasını gerektirmektedir. ${ }^{61}$

Uluslararası koruma başvurularına ilişkin tüm idari yarg1 kararlarında, başvurucuların zulme uğramaktan haklı nedenlerle korkmasının belirlenmesiyle bağlantılı olarak AİHM' in vermiş olduğu Soering/İngiltere ${ }^{62}$ kararına atıf yapılmaktadır. Mahkemenin bu kararına göre başvuranın kötü muameleye maruz kalma konusunda "gerçek bir risk" ile yüz yüze olduğuna dair maddi gerekçeler varsa, iade/sınır dışı eden Devletin sorumluluğundan bahsedilebilecektir. ${ }^{63}$ Görüldüğü üzere AİHM de bir devletin kendisine yapılan uluslararası koruma başvurusunu reddedip, başvurucuyu iade/sınır dışı ettiğinde ancak başvurucunun kötü muameleye maruz kalacağına ilişkin 'gerçek risk'i ispat eden maddi gerekçeler bulunması durumunda sorumlu olacağına karar vermiştir. Nitekim Mahkeme, A. ve K.B.F./Türkiye ${ }^{64}$ kararında başvuranların sınır dışı edilmesi halinde insanlık dışı ya da kötü muamele göreceklerine dair ciddî bir tehdidin bulunmaması gerekçesiyle başvuruları kabul edilemez bulmuştur.

İdari yargı yerleri de uluslararası koruma başvurularında ortada haklı sebeplere dayanan zulüm korkusunun ve başvurucunun kötü muamele göreceğine dair 'gerçek bir risk' in olup olmadığını nesnel ve öznel durumları dikkate alarak değerlendirmektedir. ${ }^{65}$ Nesnel unsur, başvurucunun menşe

596458 sayılı YUKK'nın 61 ve 62. maddelerinde düzenlenen mülteci ve şartlı mülteci statülerinin şartlarından biri başvurucunun ırk1, dini, tabiiyeti, belli bir toplumsal gruba mensubiyeti veya siyasi düşüncelerinden dolayı zulme uğrayacağından haklı sebeplerle korkması olarak belirlenmiştir.

${ }^{60}$ Bülent, ÇIÇEKLİ. Uluslararası Hukukta Mülteciler ve Sı ğınmacılar, Seçkin Yayınevi, Ankara, 2009, s. s. 52.

${ }^{61}$ ÇİÇEKLİ, Yabancilar ve Mülteci Hukuku, s. 247.

62 AİHM, Soering/İngiltere, Başvuru No. 14038/88, 07.07.1989.

${ }_{63}$ AİHM, Soering/İngiltere, para. 91.

${ }^{64}$ AİHM, A. ve K.B.F./Türkiye, Başvuru No. 14401/88, 12.01.1991.

65 D. 10. D., E. 2016/3515, K. 2017/903, T. 21.2.2017; D. 10. D., E. 2016/1036, K. 2016/3693, T. 11.10.2016; Ankara BİM, 10. İDD, E. 2017/1119, K. 2017/1291, T. 25.12.2017. Bkz. 
ülkesindeki koşulların somut olarak ele alınmasını gerektirmektedir. $\mathrm{Bu}$ koşullarının bilinmesi başvurucunun korkusunun ve karşı karşıya olduğu riskin inandırıcılığına etki edecektir. ${ }^{66}$ Menşe ülkeye dair bu koşullar başvurucunun öznel unsurlardaki korkusunun saptanmasında önem arz taşımaktadır. ${ }^{67}$

Aynı olaylar karşısında bireylerin aynı veya benzer tepkiler vermesi mümkün değildir. Bu nedenle menşe ülkedeki aynı nesnel durumlar da içinde yaşadığ bazı bireyler için bir ülkede siyasi düşünce ve dinsel inançların aşağılanması sorun teşkil etmezken bazıları için hayatı çekilmez kılabilmektedir. Bireylerin vermiş oldukları bu tepkilerde elbette kişilikleri önemli bir etkendir. ${ }^{68}$ Dolayısıyla bir uluslararası koruma başvurusu açısından önem taşıyan öznel unsurun değerlendirilmesinde başvurucunun olaylar karşısındaki durumu esas alınacaktır.

İdare tarafindan başvurucuların gerçek bir risk veya haklı nedenlere dayalı bir zulüm korkusu ile karşı karşıya olduklarının anlaşılabilmesi için idarenin yaptığ 1 mülakatlarda ilgililerin söz konusu zulüm korkusunu veya risk tehdidini makul bir düzeyde ortaya koyabilmeleri gerekir. Yapılan mülakat sonucunda elde edilen verilerin yeteri derecede açık olmaması durumunda bir inanılırlık değerlendirilmesinin yapılması ve kişinin içinde bulunduğu veya yaşadığı korkunun, makul olup olmadığının ve buna bağlı bir risk değerlendirmesinin yapılması gerekli görülmektedir. ${ }^{69}$

İdari yargı yerleri, uluslararası koruma talep eden başvurucunun menşe veya önceki ikamet ülkesine geri gönderilmesi durumunda zulme uğrayacağına dair korkusunu soyut iddialardan çok somut bilgi ve belgelerle ortaya koymasını beklemektedir. Örneğin, kızını üniversiteye yolladığı için Taliban tarafından üç defa uyarıldığ akrabasının Taliban tarafindan öldürüldüğü, ölüm tehdidi nedeniyle ülkesinde kaçak yaşadığı iddiasıyla yaptığı uluslararası koruma başvurusu reddedilen başvurucunun açtığı davada, Ankara Bölge İdare Mahkemesi, bu iddiaların

Lexpera İçtihat ve Bilgi Bankası.

66 ÇİÇEKLİ, Uluslararası Hukukta Mülteciler ve Sığınmacılar, s. 53; Çİ̧EKLİ, Yabancılar ve Mülteci Hukuku, s. 247.

67 Çiğdem, ALTINIŞIK/Mehmet Şahin, YILDIRIM. Mülteci Haklarının Korunması, Ankara Barosu Yayınları, Ankara, 2002, s. 13.

68 Ibid.

${ }_{69}$ D. 10. D., E. 2016/3515, K. 2017/903, T. 21.2.2017. Bkz. Lexpera İçtihat ve Bilgi Bankas1. 
başvurucunun 1rk1, dini, tabiyeti, belli bir toplumsal grubu mensubiyeti veya siyasi düşüncelerinden dolayı zulme uğrayacağını haklı kılacak sebepler olarak değerlendirmemiştir. Başvurucunun geri gönderilmesi durumunda zulme uğrayacağına ilişkin somut bilgi ve belge bulunmadığının da altını çizen Mahkeme, idarenin uluslararası koruma başvurusunun reddi işlemini hukuka uygun bulmuştur. ${ }^{70}$

Danıştay da başvurucunun geri gönderildiği halde zulme uğrayacağına dair somut bilgi, belge aramasının yanı sıra başvurucunun iddialarını dayandırdığ 1 ülkede yaşayıp yaşamadığı, adli bir işleme veya idari bir kötü muameleye tabi kılınıp kılınmadığ gibi faktörleri de incelemektedir. İddialarını uyruğu olduğu Afganistan'a ve bu ülkedeki Taliban örgütünün faaliyetlerine dayandıran ve başvurusu reddedilen yabancının açtığı dava, İran'da doğup büyümesi, tüm yakın akrabalarının İran'da ikamet etmesi, ayrıca ülkesinde hiç gözaltına alınmaması, tutuklanmaması, kötü muameleye maruz kalmaması, aile üyelerinden herhangi birinin yetkililerle sorun yaşamadığını beyan etmesi gibi nedenlerle reddedilmiştir. ${ }^{71}$ Yüksek Mahkemeye göre geri gönderilmesi durumunda başvurucuya yönelik doğrudan bir tehdit veya saldırıya uğrayacağı veya zulme maruz kalacağına ilişkin somut ve inandırıc1 bilgi ve belgeler bulunmamaktadır.

Uluslararası koruma talep eden kişinin, uzun yıllar başka ülkede yaşamasına rağmen iddialarını dayandırdığı ve uyruğu olduğu ülkeye kendi isteği ile gitmesi ve burada kötü bir muameleyle karşılaşmaması da Danıştay'a göre idarenin uluslararası koruma başvurusunun reddi işlemini hukuka uygun kılan faktörlerden biridir. Yüksek Mahkeme, menşe ülkesinde hiç gözaltına alınmamış, tutuklanmamış, kötü muameleye maruz kalmamış, aile üyelerinden herhangi birinin yetkililerle sorun yaşamamış, herhangi bir örgüte üye olmamış başvurucunun başka bir ülkede 12 yıl yaşamasını ve daha sonra menşe ülkesine isteği ile geri dönmesini dikkate alarak başvurucunun geçmişteki hangi fiili veya durum nedeniyle ülkesine iadesi halinde zulme maruz kalacağı konusunda maddi gerekçelere dayanmadığına karar vermiştir. ${ }^{72}$

Yine başka bir davada Hristiyan olduktan sonra yaşadığı yerdeki evsizlere ve bağımlılık tedavilerinin yapıldığı kampta kalanlara Hristiyanlığı tebliğ

70 Ankara BİM, 10. İDD, E. 2017/1119, K. 2017/1291, T. 25.12.2017. Bkz. Lexpera İçtihat ve Bilgi Bankasi.

71 D. 10. D., E. 2016/3515, K. 2017/903, T. 21.2.2017. Bkz. Lexpera İçtihat ve Bilgi Bankas1.

72 D. 10. D., E. 2016/1036, K. 2016/3693, T. 11.10.2016. Bkz. Lexpera İçtihat ve Bilgi Bankas1. 
eden, bu tebliği nedeniyle iki kişi tarafindan ihbar edildikten sonra evine gelen iki sivil kişinin kendisini sorduğunu öğrenip Türkiye'ye gelen başvurucunun iddiaları, Hristiyan olduktan sonra iki yıl boyunca ülkesinde hiç gözaltına alınmadığı, tutuklanmadığı, kötü muameleye maruz kalmadığı, siyasi, dini, sendikal ve/veya herhangi bir örgüte üye olmadığı, aile üyelerinden hiçbirinin ülkesinin yetkili makamlarıyla sorun yaşamadığı yönündeki beyanları nedeniyle zulme uğrayacağ 1 korkusunu ispatlamaya yeterli görülmemiştir. ${ }^{73}$

Görüldügü üzere Danıştay ve diğer idari yarg1 mercileri, başvurucunun gerçek bir risk veya haklı nedene dayalı zulüm korkusu ile karşı karşıya olup olmadığının değerlendirilmesini başvurucunun iddialarını dayandırdığı ülkede adli bir işlem görmesi, idari bir kötü muameleye maruz kalması, bir örgüte üyeliğinin olması, aile üyelerinin devlet yetkilileriyle sorun yaşaması gibi faktörlerin varlığını inceleyerek yapmaktadır. Ancak başvurucunun uzun yıllar başka ülkede yaşamasına rağmen kendi isteği ile menşe ülkesine dönmesi gibi başvuruya özel durumları da inandırıcılık bakımından göz önüne almaktadır.

İdarenin başvurucunun nesnel ve öznel durumuna yönelik yaptığ1 incelemenin yanı sıra başvurucunun BMMYK'ya başvurması ve BMMYK tarafından mülteci olarak tanınmasının başvurunun sonucuna etki edip etmediği incelenmelidir.

\section{B. BMMYK'nın Başvurunun Sonuçlanmasında İşlevi}

Bireyler temel insan haklarının ve fiziksel varlıklarının korunmasını esas olarak kendi devletlerinden beklemekle birlikte bu korumanın sağlanmaması durumunda, her ne kadar kendisi doğrudan bir koruma sağlayamasa da, BMMYK'ya başvurabilirler. ${ }^{74}$ BMMYK, mülteci haklarının korunmas1 ve ihtiyaç duydukları korumanın sağlanması için uluslararası toplum adına çalışmalar yürütmektedir. ${ }^{75} \mathrm{Bu}$ örgütün görevinin kısaca mültecilere uluslararası koruma sağlamak ve mültecilerin sorunlarına kalıcı çözümler aramak olduğu görülmektedir. ${ }^{76}$

73 D. 10. D., E. 2016/2459 K. 2016/3908 T. 28.10.2016. Bkz. Lexpera İçtihat ve Bilgi Bankas1.

74 EROĞLU/TAŞKIRAN, Ibid., s. 124.

75 Elif, UZUN. "Uluslararası Hukuk Çerçevesinde BMMYK'nın Yapısı, Görevleri ve Uluslararası Mülteci Hukukunun Gelişimindeki Yeri”, Göç Araştırmaları Dergisi, Y. 2016, C. 2, S. 2, s. 62 .

76 Ibid., s. 75.

384 Ankara Hacı Bayram Veli Üniversitesi Hukuk Fakültesi Dergisi C. XXIII, Y. 2019, Sa. 4 
Mülga 1994 Yönetmeliği'nin BMMYK'nın fonksiyonunu düzenlediği 7. maddesine göre "Íçişleri Bakanlığl, Türkiye'ye iltica eden veya başka bir ülkeye iltica etmek üzere Türkiye'den ikamet izni talep eden münferit yabancılara ilişkin işlemler ile barınma, iaşe, nakil, üçüncü ülkelere kabul, gönüllü geri dönüş, pasaport ve vize temini gibi hususlarda (...) Birleşmiş Milletler Mülteciler Yüksek Komiserliği (...) gibi uluslararası kuruluşlar ve sivil toplum örgütleri ile işbirliğinde bulunabilir."

6458 sayılı YUKK yürürlüğe girmeden önce Türkiye'nin Cenevre Sözleşmesi'ne koyduğu coğrafi sınırlama nedeniyle Türkiye'den iltica talep eden yabancılar hakkında BMMYK ile ulusal makamların izledikleri yol birbirinden farklılık göstermekteydi. ${ }^{77}$ Türkiye'nin koymuş olduğu bu sınırlama nedeniyle BMMYK iltica/sığınma statüsünün belirlenmesinde daha aktif olması gerektiğini düşünmüştür. ${ }^{78}$ Ayrıca Mülga 1994 Yönetmeliği’nde idarenin BMMYK ile işbirliği yapabileceği düzenlenmişken bu işbirliğinin mülteci statüsünün belirlenmesi konusunda nasıl gerçekleşeceği konusunda bir düzenleme yer almamıştır. ${ }^{79}$

6458 sayılı YUKK öncesi uygulamaya bakıldığında özellikle uluslararası koruma talep eden yabancıların üçüncü ülkelere yerleşimi konusunda işbirliği yapıldığg1 görülmektedir. $\mathrm{Bu}$ uygulamada etkili olan faktörlerden biri de Cenevre Sözleşmesi’nin 31/2. maddesidir. Söz konusu düzenlemeye göre "Taraf Devletler, bu mültecilerin diğer bir ülkeye kabullerini săglamak için makul bir süre ve gerekli bütün kolaylıkları sağlarlar." Cenevre Sözleşmesi'nin bu uygulamaya etki eden bir başka önemli maddesi ise 33. maddedir. Buna göre "hiçbir Taraf Devlet, bir mülteciyi, ırkl, dini, tâbiiyeti, belli bir sosyal gruba mensubiyeti veya siyasi fikirleri dolayısıyla hayatı ya da özgürlüğ̈̈ tehdit altında olacak ülkelerin sınırlarına, her ne şekilde olursa olsun geri göndermeyecek veya iade etmeyecektir."

Gerçekten de 6458 sayılı YUKK öncesi idari yarg1 yerlerinin vermiş olduğu birçok kararda Cenevre Sözleşmesi’nin 31 ve 33. maddesine dayanarak BMMYK’nın mülteci statüsü tanıdığ 1 kişinin sınır dış1 ${ }^{80}$ edilmemesi gerektiği,

77 BMMYK'nın prosedürü hakkında detaylı bilgi için bkz. ALTINIŞIK/YILDIRIM, Ibid., s. 20.

78 ÇİÇEKLİ, Uluslararası Hukukta Mülteciler ve Sığınmacılar, s. 162.

79 Ibid., s. 162.

80 Sınır dışı etme işlemleri 1961 Anayasası'na kadar Danıştay tarafından hükümet tasarrufu kabul ediliyor ve bu işlemlerin idari davaya konu edilemeyeceğine karar veriliyordu. 
üçüncü ülkeye yerleşmesi için gerekli kolaylığın sağlanması gerektiği ve üçüncü ülkeye yerleşene kadar sığınmacı olarak kabulü ile geçici süre ikametine izin verilmesi gerektiği vurgulanmıştır. ${ }^{81}$

Danıştay’ın bazı hallerde başvurucunun BMMYK'ya yapmış olduğu başvuru sonuçlana kadar sınır dışı edilmemesi gerektiğine hükmetmiştir. Yüksek Mahkeme'ye göre "siyasi nedenlerle yargllanma baskısından kurtulmak amacıyla Türkiye’ye geldiğini iddia eden davacının, ülkesine iade edilmesi halinde bask ve zulüm görme tehlikesi altında bulunması nedeniyle BMMYK'ya yaptığ iltica başvurusu sonuçlanana kadar Cenevre Sözleşmesinin 33. maddesi uyarınca üçüncü bir ülkeye gitmek üzere sı̆̆ınma talebinin kabul edilmesi gerekirken" bu talebin reddedilerek başvurucu hakkında sınır dışı etme kararı alınması hukuka aykırıdır. ${ }^{82}$

Ancak 6458 sayılı YUKK sonrası Danıştay'ın BMMYK'nın uluslararası koruma başvurularındaki işlevine ilişkin içtihatlarında bir değişim gözlenmektedir. Konuya ilişkin 6458 sayılı YUKK'nın uluslararası koruma süreçlerinde işbirliğini düzenleyen 92/1. maddesi esasen mülga 1994 Yönetmeliği'nin 7. maddesiyle aynıdır. ${ }^{83}$ Maddenin 2. fikrasına

Bkz. Aysel, ÇELIKEL/Günseli, ÖZTEKIN GELGEL. Yabancılar Hukuku, Beta Yayınevi, İstanbul, 2011, s. 116. Lütfi Duran, Danıştay'ın sınır dışı etme işlemini hükümet tasarrufu kabul ettiğine ilişkin 1960 yılına dek yalnızca bir tek yayınlanmış karar örnek gösterildiğini, Danıştay'ın 1950'den sonra bu içtihadı sürdürmediğini belirtmektedir. Bkz. Lütfi, DURAN. "Yabancıların Türkiye'den Sınırdışı Edilmesi”, İnsan Hakları Yıllığı, Y.2, 1985, s. 17, 18.

81 D. 10. D., E. 1999/749, K. 2000/2755, T. 25.05.2000. Bkz. Vahit, DOĞAN/Hasan, ODABAŞI. Vatandaşlık ve Yabancılar Hukuku, Seçkin Yayınevi, Ankara, 2004, s. 300. D. 10. D., E. 1998/1481, K. 2000/131, T. 20.01.2000; D. 10. D., E. 1999/5498, K. 2001/822, T. 14.03.2001; D. 10. D., E. 2004/3045, K. 2007/3124, T. 30.05.2007; D. 10. D., E. 2008/4360, K. 2008/6301, T. 24.09.2008; D. 10. D., E. 2009/645, K. 2009/10284, T. 09.12.2009. Bkz. EKŞİ/Çi̧̇EKLİ, Ibid., s. 124 vd. Ayrıca BMMYK tarafından başvurucunun mülteci statüsü verilmemesinin idarenin sınır dışı etme kararını hukuka uygun kılan faktörlerden birini oluşturduğu dava için bkz. D. 10. D., E. 2005/3660, K. 2007/6541, T. 28.12.2007. Bkz. EKŞİÇIÇEKLİ, Ibid., s. 151. Başvurucuya BMMYK tarafindan mülteci statüsü tanınmadığı halde başvurucunun üçüncü ülkeye yerleşmesi konusunda BMMYK ile işbirliği yapıldığına ilişkin bkz. D. 10. D., E. 1997/6373, K. 2000/130, T. 20.01.2000. Bkz. Yakup, BAL/Mustafa, KARABULUT/Yahya, ŞAHIN. Danıştay 10. Daire Kararları, C. I, Turhan Kitabevi, Ankara, 2003, s. 719.

82 D. 10. D., E. 2014/3867, K. 2016/513, T. 26.1.2016. Bkz. Lexpera İçtihat ve Bilgi Bankas1.

836458 say11 YUKK'nın 92/1. maddesi: Bakanlık, bu Kısımda yazılı uluslararası koruma süreçleriyle ilgili konularda, 5/5/1969 tarihli ve 1173 sayılı Milletlerarası Münasebetlerin Yürütülmesi ve Koordinasyonu Hakkında Kanun çerçevesinde Birleşmiş Milletler Mülteciler Yüksek Komiserliği, Uluslararası Göç Örgütü, diğer uluslararası kuruluşlar ve sivil toplum kuruluşlarıyla iş birliği yapabilir. 
göre "[Cenevre] Sözleşme[sinin] hükümlerinin uygulanmasina nezaret etme görevini yerine getirmesinde, Birleşmiş Milletler Mülteciler Yüksek Komiserliğiyle gerekli iş birliği sağlanır." Aynı maddenin 3. fikrasında ise BMMYK'nın uluslararası koruma başvurusunda bulunan yabancılara erişiminin sağlanması ve her aşamada görüşlerini yetkililerle paylaşabileceği düzenlenmiştir.

Danıştay'ın önceki içtihatlardan farklı olan kararına konu olan uyuşmazlık hakkında ilk olarak Ankara 1. İdare Mahkemesi, bildirim yükümlülüğünü üç kez üst üste ihlal ettiği için hakkında başvurunun geri çekilmiş sayılması kararı alınan başvurucunun BMMYK tarafından verilen mültecilik belgesine sahip olmasını da dikkate alarak idarenin işlemini iptal etmiştir. ${ }^{84}$ Ancak davanın temyiz incelemesinde Danıştay başvurucunun bildirim yükümlülüğüne ilişkin mazeretlerini geçerli kabul etmeyerek idarenin işlemini hukuka uygun bulmuş ve ilk derece mahkemesinin kararını bozmuştur. Yüksek Mahkeme, yerel mahkemenin göz önüne aldığı başvurucunun BMMYK'nın verdiği mültecilik belgesine sahip olmasına ilişkin ise önemli bir içtihatta bulunmuştur. Danıştay'a göre "6458 sayll Kanun'un 78. maddesi uyarınca uluslararası koruma talebinde bulunan yabancılarla ilgili olarak karar merciin Göç İdaresi Genel Müdürlü̆̆̈̈ olduğu, Birleşmiş Milletler Mülteciler Yüksek Komiserliği'nin 1951 tarihli Cenevre Sözleşmesinin 35. maddesi gereğince tanınan işbirliği yapma görevi doğrultusunda nezaret etme görevinin bulunduğu dikkate alındığında, başvuranlara mülteci, şartlı mülteci, ikincil koruma statüsü verme noktasında tek yetkili idarenin Göç İdaresi Genel Müdürlüğ̈̈ olduğu açıktır." ${ }^{\prime 5}$ Yüksek Mahkeme'nin uluslararası koruma başvurularının sonuçlamasında tek yetkili idarenin Göç İdaresi Genel Müdürlüğü olduğuna vurgu yaptığ1, BMMYK’nın yalnızca Cenevre Sözleşmesi'nin uygulanmasına nezaret etme görevinin bulunduğunun ve yabancıların 6458 sayılı YUKK uyarınca kendilerine yüklenen yükümlülükleri yerine getirmemeleri durumunda BMMYK tarafindan mülteci olarak tanınmalarının haklarında 6458 sayılı YUKK'ta öngörülen yaptırımların uygulanmayacağı anlamına gelmediğinin altını çizdiği görülmektedir.

Danıştay bir başka kararında ise hakkında BMMYK tarafından yapılmış “ülkesine isteği dışında geri göndermeye karşı korunması gerektiğine dair

\footnotetext{
${ }^{84}$ Ankara 1. İdare Mahkemesi, E. 2015/2613, K. 2016/858, T. 24.03.2016. Bkz. Lexpera İçtihat ve Bilgi Bankası.

85 D. 10. D., E. 2016/3216, K. 2017/911, T. 21.2.2017. Bkz. Lexpera İçtihat ve Bilgi Bankas1.
} 
tespit" bulunan başvurucunun uluslararası koruma başvurusunun reddi işlemini hukuka uygun bulmuş, BMMYK'nın başvurucu hakkında yaptığ 1 tespiti dikkate almamıştır. ${ }^{86}$

Danıştay'ın BMMYK'nın başvurucu hakkında mültecilik statüsü tanımasının uluslararası koruma başvurusuna etkisine ilişkin içtihadında değişim gözlenmekle birlikte, başvurucunun BMMYK'ya yapmış olduğu mültecilik başvurusu reddedildiği durumlarda, idari yarg1 yerleri bu durumu idarenin işlemini hukuka uygun kılan etkenlerden biri olarak değerlendirmektedir. ${ }^{87}$

Uluslararası koruma başvurularının incelendiği kararlarda, idari yarg1 yerleri başvurucunun beyanlarının tutarlı olmasını da gözetmektedir.

\section{Başvurucunun Dilekçe ve Mülakatları Arasında Çelişkili İbareler Bulunması}

Uluslararas1 koruma başvuru süreci, başvurucunun kendisine ait nesnel ve öznel bilgileri iyi ve doğru bir şekilde ifade etmesi ile idarenin bu bilgileri sınaması ve başvurucunun iddialarını kontrol etmesinin bütününden oluşmaktadır.

Uluslararası korumanın amacının başvuru sahibi kişilerin ülkede ulusal ve uluslararası mevzuat hükümleri uyarınca belirlenen sebepler dışında kalmalarına izin verilmesi şeklinde değerlendirilemeyeceği de dikkate alındığında kişilerin bu korumaya uygun sebeplere sahip olup olmadığının tespitinin önemi açıktır. Bu tespit yapılırken başvurucuların tutarlı olmaları, idarenin başvuru konusunda olumlu karar vermesine etki edecektir. Aksi takdirde inandırıcılıktan uzaklaşan bu başvurular idare tarafından reddedilebilecektir.

Danıştay bu tip çelişkili beyanların mevcut olduğu başvurularda idarenin red işlemini hukuka uygun bulmaktadır. Örneğin, ilk yapılan mülakatta Taliban üyesi olduğunu ve bu örgüt adına silahlı eylemlerde bulunduğunu, daha sonraki mülakatta ise Taliban'ın bir binasında çaycılık yaptı̆̆ını, işe girmesini sağlayan akrabasının Taliban tarafından öldürülmesi nedeniyle korkup kaçtığını beyan eden başvurucunun mülakatlar arasındaki çelişkili

86 D. 10. D., E. 2016/3511, K. 2016/3850, T. 25.10.2016. Bkz. Lexpera İçtihat ve Bilgi Bankas1.

87 Ankara BİM, 10. İDD, E. 2017/445, K. 2017/780, T. 27.9.2017. Bkz. Lexpera İçtihat ve Bilgi Bankası. 
beyanları idarenin başvurunun reddi işlemini hukuka uygun kılan bir gerekçe olmuştur. $^{88}$

Benzer şekilde ilk mülakatta boşandığı eşinin Türkiye'ye gelmesi nedeniyle Türkiye'ye geldiğini, ikinci mülakatta ise eşinin öldüğünü öğrendiğini, aslında babasının ettiği eziyetten kaçmak için Türkiye’ye geldiğini beyan eden ve eski eşiyle Türkiye'ye geldikten makul bir süre içinde evlenmeyen, eski eşinin başka biri ile yaşadığı tespit edilen başvurucunun beyanları ve olgular arasındaki çelişkiler de davanın reddine gerekçe oluşturmuştur. ${ }^{89}$

\section{SONUÇ}

6458 sayıl1 YUKK'nın yürürlüğe girmesinden önce Cenevre Sözleşmesi ile birlikte 1994 Yönetmeliği'nin iltica/sı̆̆ınma başvurularının değerlendirilmesinde uygulandığı görülmektedir. 6458 sayılı YUKK'nın yürürlüğe girmesi ile daha önce dağınık olan uluslararası koruma mevzuatı bir bütün haline getirilmiş ve kanuni dayanak kazanmıştır.

Mülga 1994 Yönetmeliği’nde mülteci ve sığınmacı statüleri tanımlanmışken, 6458 sayılı kanun ile bu statüler uluslararası koruma üst başlığında toplanmış, sığınmacı kavramı yerine şartlı mülteci kavramı tercih edilmiş ve uluslararası koruma türleri mülteci, şartlı mülteci ve ikincil koruma olarak belirlenmiştir.

Uluslararası koruma başvurusu esas itibariyle bir idari başvurudur. İdareye yapılan uluslararası koruma başvuruları hakkında idarenin tesis ettiği kabul veya red işlemleri de idari işlemdir. Bu belirlemeyle uyumlu şekilde ${ }^{90}$ uluslararası koruma başvurularının reddi işlemlerine karşı idari yargıya başvurulabileceği 6458 sayılı YUKK ile düzenlenmiştir.

İdari yarg1 yerlerinin verdiği kararlar incelendiğinde 6458 sayıl1 kanun sonrası bazı değişimler gözlenmektedir. Öncelikle idare ve bölge idare mahkemeleri ile Danıştay, uluslararası koruma başvurusuna ilişkin davaları artık oturmuş bir sistematik içinde incelemektedir. Kararlarda, AİHM'in konuyla ilgili kararlarına atıf yapıldıktan sonra temel ilkeler ortaya

88 D. 10. D., E. 2016/3517, K. 2016/3851, T. 25.10.2016. Bkz. Lexpera İçtihat ve Bilgi Bankas1.

89 D. 10. D., E. 2016/3089, K. 2017/904, T. 21.2.2017. Bkz. Lexpera İçtihat ve Bilgi Bankas1.

90 İdari gözetim kararı da bir idari işlem olmasına rağmen 6458 sayılı Kanun'un 68/7. maddesi uyarınca sulh ceza hakimlerinin denetimine tabi kılınmıştır. 
konulmaktadır. Daha sonra bu temel ilkeler ışığında başvurucunun durumu öznel ve nesnel koşullar dikkate alınarak değerlendirilmektedir. İdari yarg1 yerlerinin başvurucunun soyut iddialarını dikkate almadığı, gerçek bir risk ve haklı nedene dayalı bir zulüm korkusu ile karşı karşıya olduğunu somut olarak ispatlamasını beklediği görülmektedir. Başvurucunun iddialarını dayandırdığ 1 ülkede gözaltına alınması, tutuklanması veya ailesinin ülke yetkilileriyle sorun yaşaması bu somut gerekçelere örnek olarak verilebilir.

Ayrıca Danıştay'ın uluslararası koruma statülerinin verilmesinde tek yetkilinin Göç İdaresi Genel Müdürlüğü olduğunu vurgulayarak BMMYK'nın başvuru sonucuna etkisi bakımından önceki Danıştay içtihatlarından uzaklaştı̆̆ önemli bir değişiklik olarak tespit edilmiştir. Bu bakımdan 6458 sayılı Kanunun kendisine zorunlu kıldığı yükümlülükleri yerine getirmeyen birinin BMMYK tarafından mülteci olarak tanınması, bu kişinin ilgili yaptırımlara tabi kılınmasını engellemeyecektir.

İdari yarg1 yerleri başvuruculardan iddialarını somut şekilde ispatlamasını beklediği gibi idarenin de başvuruyu reddettiği hallerde bunu gerekçelendirmesini, somut bilgi ve belge olmadan işlem yapmamasını talep etmektedir.

6458 sayılı Kanun ile getirilen uluslararası koruma başvurularına ilişkin yarg1 kararlarının genel olarak birbiriyle tutarlı oldukları ve idari yargı yerlerinin başvurucuların iddiaları ile başvurunun reddi kararı arasında dikkatli bir inceleme yaptıkları görülmüştür. Esasen idari yarg1 yerlerinin başvurucuların iddialarını detaylı şekilde araştırmaları bir yükümlülük teşkil etmekte, aksi halde başvurucunun Anayasal hakları ihlal edilebilmektedir. Nitekim Anayasa Mahkemesi'ne göre "başvurucunun AIHM'in kararlarına ve insan hakları alanında araştırma yapan sivil toplum örgütlerinin raporlarına konu olmuş iddialarının doğru olup olmadi ̆̆ hususunda yargılama aşamasında herhangi bir araştırma yap [mayan], kararda da anılan iddialara neden itibar edilmediği konusunda bir değerlendirmeye yer ver[meyen] (...) idare mahkemesi, iddia edilen riske ilişkin araştırma ve değerlendirme yapma yükümlülü̆̈̈̈nü yerine getirme[miş olacaktır]."

6458 sayılı YUKK uyarınca yapılan uluslararası korumaya ilişkin idari işlemlerden başvurunun yapılması ve sonuçlandırılmasıyla ilgili idari işlemlerin ağırlıklı olarak uyuşmazlık konusu olduğu görülmekle birlikte

91 AYM, Azizjon Hikmatov Başvurusu, Başvuru No. 2015/15582, 10.05.2017, R.G. T. 07.06.2017, S. 30089, para. 73, 74 . 
zaman içinde YUKK uyarınca yapılan diğer idari işlemlerle ilgili de içtihatların oluşması beklenmektedir.

\section{KAYNAKÇA}

ALTINIŞIK, Çiğdem/YILDIRIM, Mehmet Şahin: Mülteci Haklarının Korunmas1, Ankara Barosu Yayınlar1, Ankara, 2002.

ALTINOK ÇALIŞKAN, Elif: Mülteciler ve Sı̆̆ınmacılar Hakkında İdarenin Görevleri-Yetkileri ve Yargısal Denetim, Yayımlanmamış Doktora Tezi, Dokuz Eylül Üniversitesi, İzmir, 2013.

AYBAY, Rona: Yabancılar Hukuku, İstanbul Bilgi Üniversitesi Yayınları, İstanbul, 2007.

BAL, Yakup/KARABULUT, Mustafa/ŞAHIN, Yahya: Danıştay 10. Daire Kararları, C. I, Turhan Kitabevi, Ankara, 2003.

BOZBEYOĞLU, Eda: "Mülteciler ve İnsan Hakları", Moment Dergi, Y. 2015, S. 2 (1), ss. 60-80.

BUZ, Sema: "Türkiye Sığınma Sisteminin Sosyal Boyutu”, TBB Dergisi, Y. 2008, S. 76, ss. 120-130.

ÇAKRAN, Şebnem/EREN, Veysel: "Mülteci Politikası: Avrupa Birliği ve Türkiye Karşılaştırması”, Mustafa Kemal Üniversitesi Sosyal Bilimler Enstitüsü Dergisi, Y. 2017, C. 14, S. 39, ss. 1-30.

ÇELIK, Neşe Baran: “Türk Hukukunda Uluslararası Koruma Başvurusunda Bulunan veya Uluslararası Korumadan Yararlanan Yabancıların Hak ve Yükümlülükleri”, İnönü Üniversitesi Hukuk Fakültesi Dergisi, Özel Say1, Y. 2015, C. 1, ss. 67-148.

ÇELIKKEL Aysel/ÖZTEKİN GELGEL Günseli: Yabanc1lar Hukuku, Beta Yayınevi, İstanbul, 2011.

ÇİÇEKLİ, Bülent: "Mülteci, Sı̆̆ınmacı ve Göçmenler: Sınıflandırma ve Yasal Statünün Belirlenmesine İlişkin Sorunlar”, Vatandaşlık, Göç, Mülteci ve Yabancılar Hukukundaki Güncel Gelişmeler, TBB Yayınları, Ankara, 2010, ss. 327-362.

ÇİÇEKLİ Bülent: Uluslararası Hukukta Mülteciler ve Sı̆̆ınmacılar, Seçkin 
6458 Sayılı Kanun Uyarınca Yapılan Uluslararası Koruma Başvurularının...

Yayınevi, Ankara, 2009.

ÇİÇEKLİ, Bülent: Yabancılar Hukuku, Seçkin Yayınevi, Ankara, 2013.

ÇİÇEKLİ, Bülent: Yabancılar ve Mülteciler Hukuku, Seçkin Yayınevi, Ankara, 2016.

DOĞAN, Vahit/ODABAŞI, Hasan: Vatandaşlık ve Yabancılar Hukuku, Seçkin Yayınevi, Ankara, 2004.

DURAN, Lütfi: "Yabancıların Türkiye'den Sınırdışı Edilmesi”, İnsan Hakları Y1llı̆̆1, Y. 2, 1980, ss. 3-34.

EKŞİ, Nuray: Yabancılar Hukukuna İlişkin Temel Konular, Beta Yayınevi, İstanbul, 2007.

EKŞİ, Nuray: Yabancılar ve Uluslar arası Koruma Hukuku, Beta Yayınevi, İstanbul, 2016.

EKŞİ, Nuray/ÇİÇEKLİ, Bülent: Yabancılar ve Mülteci Hukukuna İlişkin Danıştay 10. Daire Kararları, Beta Yayınevi, İstanbul, 2012.

ERGÜVEN, Nasıh Sarp/ÖZTURANLI, Beyza: "Uluslararası Mülteci Hukuku ve Türkiye”, AÜHFD, Y. 2013, S. 62 (4), ss. 1007-1061.

EROĞLU ENDER, Canan/TAŞKIRAN, Ruken: "Sığınma Hakkı ve Mültecilerin Durumu”, TBB Dergisi, S. 2002/1, ss. 105-128.

ERTEN, Rifat: "Yabancılar ve Uluslararası Koruma Kanunu Hakkında Genel Bir Değerlendirme", Gazi Üniversitesi Hukuk Fakültesi Dergisi, C. XIX, Y. 2015, S.1, ss. 3-51.

KIVILCIM, Zeynep: "Yabanc1lar ve Uluslararası Koruma Kanunu ile Geçici Koruma Yönetmeliği: Toplumsal Cinsiyet Perspektifinde Bir Değerlendirme", Ankara Üniversitesi SBF Dergisi, Y. 2016, C. 71, S. 3, ss. 919-940.

ODMAN, Tevfik: Mülteci Hukuku, AÜSBF, Ankara, 1995.

ÖZGÜR, Nurcan/ÖZER, Yeşim: Türkiye'de Sı ğınma Sisteminin Avrupalılaştırılması, Derin Yayınları, İstanbul, 2010.

ÖZTÜRK, Neva Övünç: "Geçici Korumanın Uluslararası Koruma Rejimine Uyumu Üzerine Bir İnceleme", Ankara Üniversitesi Hukuk Fakültesi Dergisi, Y. 2017, S. 66 (1), ss. 201-216. 
ÖZTÜRK, Neva Övünç: “Avrupa Birliği Temel Haklar Şartında Yer Alan Sığınma Hakkının Tahlili”, İnönü Üniversitesi Hukuk Fakültesi Dergisi, Y. 2012, C. 3, S. 2, ss. 187-229.

SAV, Özden: "Uluslararası Hukuk Açısından "Sı̆̆ınma", "Göç", "Nüfus Mübadelesi", "Vatansızlık" Gibi "Silahlı Çatışma" Bağlantılı Nüfus Sorunları", TBB Dergisi, S. 2016 (124), ss. 497-558.

TÜRKOĞLU, Oğuzhan: "Mülteciler ve Ulusal/Uluslararası Güvenlik", Uludağ Üniversitesi İktisadi ve İdari Bilimler Dergisi, Y. 2011, C. XXX, S. 2, ss. 101-118.

UZUN, Elif: "Uluslararası Hukuk Çerçevesinde BMMYK'nın Yapısı, Görevleri ve Uluslararası Mülteci Hukukunun Gelişimindeki Yeri”, Göç Araştırmaları Dergisi, Y. 2016, C. 2, S. 2, ss. 60-85. 
